\title{
Polygenetic Ophiolite Belt of the California Sierra Nevada: Geochronological and Tectonostratigraphic Development
}

\author{
Jason B. SAleeby
}

Division of Geological and Planetary Sciences, California Institute of Technology, Pasadena, California 91125

\begin{abstract}
The assumption that ophiolite sequences are generated at essentially one point in geologic time by the process of sea-floor spreading is critical for modern concepts in the tectonics of ophiolites and for topics dealing with their structure and petrology. However, this assumption has only been verified in a few locations by an integrated geochronological and structural-stratigraphic approach. Many ophiolite sections are reconstructed from structurally disrupted sequences with the idealized ocean floor model in mind. Such reconstructions are prone to error without adequate age control on each of the reconstructed fragments. This is a significant problem in structurally complex regions where more than one generation of ophiolite may be present. In this paper new $\mathrm{Pb} / \mathrm{U}$ zircon ages are presented for key locations along a $375 \mathrm{~km}$ segment of the western Sierra Nevada ophiolite belt. These age data are combined with structural-stratigraphic observations and published ages, and significant tectonic implications for the ophiolite belt emerge. Three different ophiolitic assemblages are recognized with igneous ages of about 300,200 and 160 m.y. B.P. Rocks of the $300 \mathrm{~m}$.y. assemblage are in a completely disrupted array of metamorphic tectonite slabs and serpentinite-matrix melange. Fragments of upper Paleozoic seamounts occur in association with the ophiolitic melange, and together these assemblages constitute the basement framework for the western Sierra. $\mathrm{Pb} / \mathrm{U}$ and $\mathrm{K} / \mathrm{Ar}$ isotopic systematics are complex within this framework and indicate a polymetamorphic history. Systematics in the 200 and $160 \mathrm{~m}$.y. assemblages are less complex and give tighter igneous age constraints. Rocks of the $200 \mathrm{~m}$.y. assemblage are in a semi-intact state with only local tectonite and melange zones. Rocks of the 160 m.y. assemblage are intact, but nevertheless deformed. Both the 200 and 160 m.y. assemblages have equivalent age basinal volcanic-sedimentary sequences that lie unconformably above the ophiolitic melange basement. In each case the basinal sequences locally extend conformably into the upper stratigraphic levels of the age-equivalent ophiolite sections. These relations along with vestiges of intrusive contacts between the edges of both younger ophiolites and the melange basement indicate that the younger ophiolites underwent igneous formation in proximity to the melange basement. The Sierran ophiolite belt is considered to have formed by a multistage process initiated by the early Mesozoic tectonic accretion of upper Paleozoic sea-floor in general proximity to the ancient continental margin. Regional metamorphism and ophiolitic melange resulted. This accretionary nucleus became the basement of Jurassic-age primitive volcanic arc terranes which underwent rifting episodes during the production of the 200 and $160 \mathrm{~m}$.y. ophiolites. The rifting episodes resulted in the formation of sedimentary basins which were the depositional sites of volcanic-sedimentary sequences. Non-volcanic sources for the basinal sedimentary rocks include the melange basement and continental margin terranes. Contact zones between pre-existing basement and the juvenile ophiolitic sequences created during the rifting episodes consist of dynamothermal metamorphic aureoles, protoclastic deformation zones and cross-cutting dikes. Such edge-zone assemblages are in most localities obscurred or destroyed by superimposed deformations resulting from convergent and perhaps transform motions along basin edges. Both the 200 and $160 \mathrm{~m} . \mathrm{y}$. basins were destroyed by compressional orogenic episodes shortly after their formational episodes. Destruction of young ophiolite floored basins may be a common course of events when small oceanic-type plates are generated along continental margin environments. Such tectonic settings are ideal for the emplacement of young ophiolite sheets.
\end{abstract}

\section{INTRODUCTION}

Ophiolite sequences consist of ultramafic tectonites, cumulate gabbro, sheeted dikes, and pillow basalt. These are commonly thought to be on-land fragments of oceanic crust and upper mantle [Coleman, 1977]. Modern studies in the petrology and tectonics of ophiolites have relied strongly on the assumption that in a given ophiolite the main igneous mass was generated at essentially one point in geologic time. In a plate tectonic context this is assumed to have been the time of sea-floor spreading formation of the sequence. Operating under this assumption numerous investigators have looked at ophiolites with focus on the petrologic processes operating at mid-ocean ridges, and on the ancient interactions between oceanic plates, and their continental margin sites of emplacement. However, the assumption that a given ophiolite is in fact the product of one igneous constructional stage has only been documented for a few of

Copyright $(\mathcal{C} 1982$ by the American Geophysical Union. the more intact sequences such as the Semail ophiolite in northern Oman and perhaps the Coast Range ophiolite belt of California [Hopson et al., 1980; Tilton et al., 1981]. Proper documentation of this critical assumption requires detailed field observations of the primary structural relations within the ophiolite igneous suite in conjunction with geochronological and stratigraphic studies.

This paper summarizes geochronological, stratigraphic and structural data from key locations along a 375-km-long stretch of the Sierra Nevada ophiolite belt. The area of interest occurs along the central and southern parts of the western foothills metamorphic complex which bounds the edge of the Sierra Nevada batholith (Figure 1). Contrasting metamorphic and deformational histories in different segments of the ophiolite belt, along with regional stratigraphic relations suggest the presence of more than one age of ophiolite. This is clearly demonstrated by the geochronological data presented below. Furthermore, these investigations show that the Sierran ophiolite belt developed in three 
igneous formation stages widely spaced in time and that rocks of the two younger stages formed by rifting within a tectonic framework constructed from rocks of the oldest stage. The rifting episodes gave rise to sedimentary basins that underwent deformation and metamorphism shortly after their formation. It is not implied that such complexities are typical of all or most ophiolites, but rather the igneous and stratigraphic development of each ophiolite should be considered independently and without a strong bias toward the idealized ocean floor model.

The approach taken in this study was to look in detail at critical structural and stratigraphic relations within the Sierran ophiolite belt and to collect samples for zircon $\mathrm{Pb} / \mathrm{U}$ analyses with the intent of dating specific igneous and stratigraphic relations. In the discussions that follow, the geochronological data are considered within a context that includes the field settings and metamorphic petrology of the samples. In such a context the complex relative chronology of petrogenetic and deformational episodes derived from geological data can be directly related to an absolute chronology based on the zircon data. In order to fully appreciate the geological settings of the age samples, a brief introduction to the regional setting of the ophiolite belt and its relations with neighboring metamorphic units is required.

\section{Regional Setting of the Ophiolite Belt}

The aerial distribution of the major rock units of the western and northern Sierra Nevada are shown in Figure 1. Note that the east-west scale has been expanded to help clarify the spacial relations between the belt-like rock units. Attention in this paper will focus on ophiolitic rocks of the central Sierran foothills between the Pine Hill and Penon Blanco areas, and to a lesser extent on rocks of the KingsKaweah area exposed in the southern foothills. The main exposures of ophiolitic rocks in the central foothills occur as a semi-continuous northwest-trending belt which is bounded by belts of low-grade slate, greenstone, and chert-argillite. Ophiolitic rocks of the southern foothills are bounded by batholithic and high-grade metasedimentary rocks.

The ophiolitic rocks are divided into two structural-setting groups in Figure 1. The oldest group yields zircon ages in both the 300 and $200 \mathrm{~m}$.y. range, and is characterized by a complex structural history involving the widespread development of metamorphic tectonites and melange. The structural complexities of this group are such that subdivision into the more significant 200 and $300 \mathrm{~m} . \mathrm{y}$. age groups is not possible at the scale of Figure 1. For the purposes of this discussion the 200 and $300 \mathrm{~m} . \mathrm{y}$. age groups are shown together because of their occurrence as or close association with ophiolitic melange. Melange is used as a descriptive term for mappable bodies of deformed rock which lack internal stratigraphic continuity, and whose overall structure is characterized by intact fragments encased within a finegrained matrix. Ophiolitic melange of the Sierran foothills consists of mafic, ultramafic and sedimentary blocks encased in a serpentinite matrix. Ophiolitic rocks which give $300 \mathrm{~m}$.y. ages are either from melange blocks or occur within large melange-bounded tectonite slabs. The $200 \mathrm{~m}$.y. ages occur in melange-bounded slabs with both tectonite and well-preserved protolith features. The 300 and $200 \mathrm{~m} . \mathrm{y}$. association extends along the entire length of the Sierra Nevada and constitutes the oldest basement element exposed along the western margin of the range.
Chert-argillite melange belts are co-extensive with the ophiolitic basement rocks, and in places intimately intermixed. Such assemblages are generally referred to as the Calaveras Formation; however, as discussed by Schweickert et al. [1977], a formational status for such a diverse mixture of rocks is inappropriate. Upper Paleozoic limestone blocks are ubiquitous in the various chert-argillite melange belts, although the most distinguishing features of the different belts are the ages of their youngest elements. Radiolarian chert and quartz-rich clastic rocks as young as Early and possibly Middle Jurassic occur in rocks west of the Melones Fault Zone and in association with the Kaweah ophiolitic melange [Behrman, 1978a, b; Irwin et al., 1978; Saleeby and Sharp, 1980]. Such rocks are referred to as central belt melange. Infolded depositional remnants and fault slivers of Jurassic volcaniclastic-slate sequences also occur locally in central belt rocks. The large belt of chert-argillite melange east of the Melones Fault zone is constrained to pre-Jurassic in age by $\mathrm{Pb} / \mathrm{U}$ and $\mathrm{K} / \mathrm{Ar}$ ages on its main metamorphicdeformation fabric [Sharp et al., 1982]. This belt constitutes the oldest of the chert-argillite melange assemblages and is referred to as the Calaveras Complex [Schweickert et al., 1977]. The age constraints of late Paleozoic to Triassic and Early Jurassic on the chert-argillite belts parallel those of the 300 and $200 \mathrm{~m}$.y. ophiolitic assemblages.

Ophiolitic rocks yielding the youngest ages extend northward from the Pine Hill area and include the Smartville block. These rocks yield numerous zircon ages which cluster between 165 and 159 m.y. Rocks of this group are generally intact and show primarily low-grade metamorphic features. The Smartville block constitutes a broad anticlinal exposure of the plutonic and volcanic members of a continuous ophiolite section [Menzies et al., 1975; Xenophontos and Bond, 1978]. Within its upper pillow lava section occur volcaniclastic strata which are extensions of the western Jurassic volcaniclastic-slate belt (Figure 1).

The Jurassic volcaniclastic-slate belts consist primarily of mafic with lesser intermediate and silicic tuffs, breccias, pillows and flows. Such volcanic rocks are intercalated on all scales with mudstone-sandstone-conglomerate flysch derived from first cycle volcaniclastic material, and uplifted chert-argillite, continental margin and ophiolitic source terranes. Mudstone, sandstone and fine tuffs of this assemblage contain a well-developed slaty cleavage whereas coarse volcanic units generally lack deformation fabrics. Much of the volcaniclastic-slate assemblage is late-Middle to Late Jurassic in age [Clark, 1964], although some volcanic intervals exposed in the eastern belt are of probable Jura-Trias age [Sharp and Wright, 1981]. These older volcanic rocks are similar to the Penon Blanco volcanics which, as discussed below, are of Jura-Trias age. An outstanding feature of both the mid- to Late Jurassic and Jura-Trias volcanic rocks is the predominance of ankaramitic or conspicuously clinopyroxene-phyric olivine basalt. Volcaniclastic-slate units of the Mother Lode and Western belts and similar strata exposed along the Kaweah melange (Figure 1) lie unconformably above central belt and ophiolitic basement rocks. This relationship in conjunction with the extension of such strata conformably into the upper levels of the Smartville ophiolite is suggestive of a primary link between the older and younger ophiolitic age groups. This is one of the major points of this paper and will be discussed at length below. 
Regional deformation, metamorphism and ophiolite emplacement in the western Sierra Nevada have traditionally been viewed as the results of the Late Jurassic Nevadan orogeny [Hinds, 1934; Moores, 1970; Bateman and Clark, 1974]. It is now clear that the Nevadan orogeny is the latest in a series of early Mesozoic orogenic pulses, each of which involved metamorphism and thrusting of ophiolitic assemblages [Saleeby, 1980; this paper]. The main expression of the Nevadan orogeny was the development of slaty cleavage in mid- to Late Jurassic strata and rotations and flattening distortions in melange fabrics of the underlying basement.
An east-dipping Nevadan thrust zone separates the eastern volcaniclastic-slate belt from the Calaveras Complex [Schweickert et al., 1982], and the northern and eastern margins of the Smartville block appear to be Nevadan-age thrust faults. The Melones fault zone is traditionally viewed as a Nevadan suture. However, this fault zone is clearly not a fundamental break inasmuch as similar Jurassic volcaniclastic-slate units occur on both sides of the fault (Figure 1), and as discussed below similar pre-Jurassic basement elements and Jurassic intrusive sequences occur on both sides. The Melones fault zone in many localities truncates Neva-

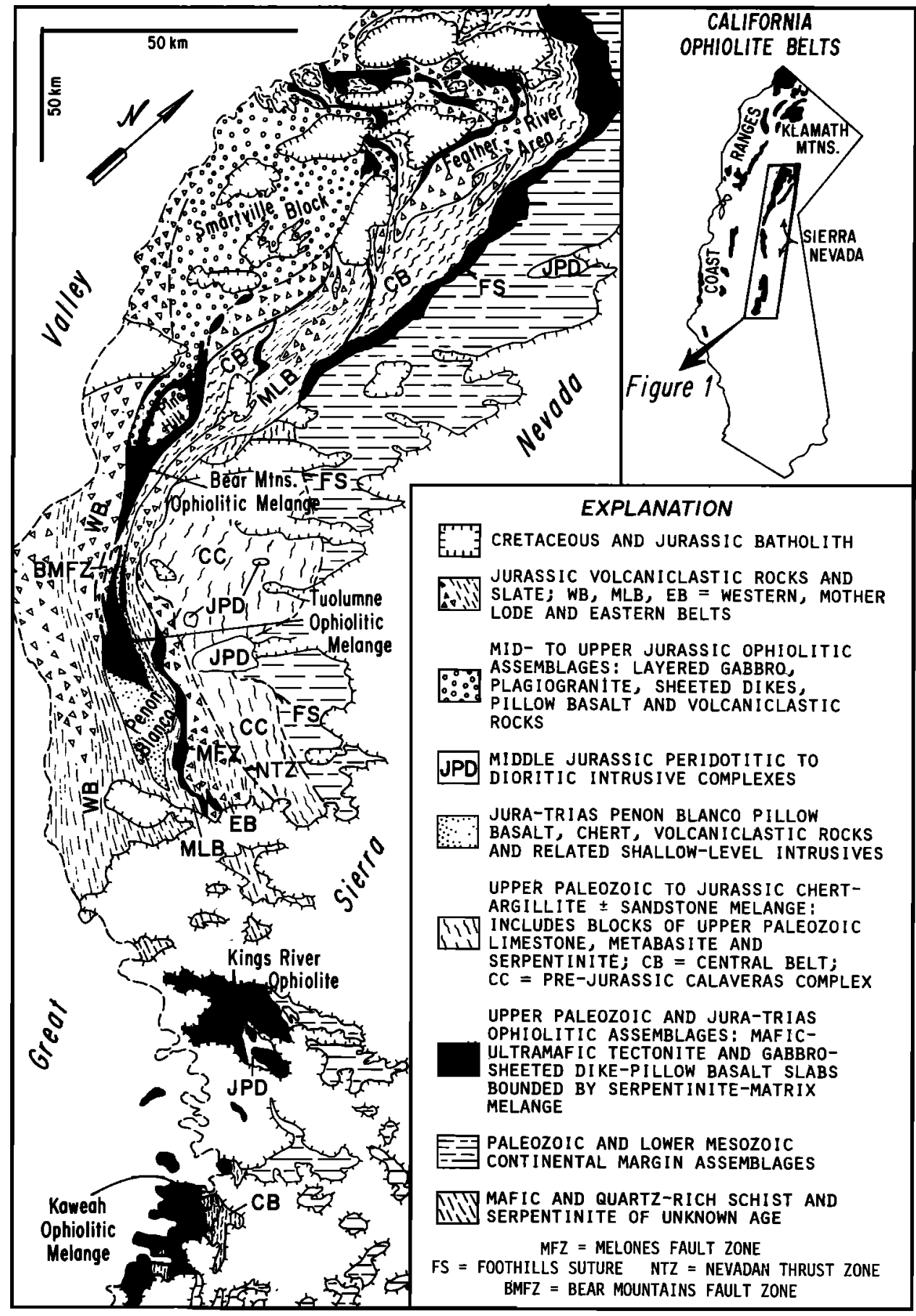

Fig. 1. Generalized map showing major metamorphic rock units of the western and northern Sierra Nevada. Note that east-west scale does not equal north-south scale. Geology after Jennings [1977], Saleeby [1980], Schweickert et al. [1982], and Snoke et al. [1982]. 
dan-age cleavages, although at regional scales it is concordant with such structures. Right-slip, thrusting and combinations of these mechanisms have been suggested for the Melones fault zone [Clark, 1960; Saleeby, 1980; Schweickert et al., 1982].

The most fundamental structural break in the Sierra Nevada is the Foothills suture (Figure 1). The Foothills suture separates rocks within a clearly oceanic or ophiolitic basement regime to the west from rocks of continental margin affinity to the east. The continental margin rocks consist primarily of Paleozoic and lower Mesozoic quartzite, marble, deformed granitoids and silicic to intermediate volcanic sequences. Intense deformation and amphibolite facies metamorphism apparently related to the juxtapositioning of the continental margin and oceanic basement rocks took place in Late (perhaps latest) Triassic time [Sharp et al., 1982]. Various movement patterns involving westward overthrusting and right-slip have been proposed for the suturing of these two different rock regimes [Schweickert, 1977; Saleeby, 1980]. The Late Triassic metamorphic-deformational episode exhibited along the Foothills suture appears to correspond with the time constraints placed on metamorphism and melange development in ophiolitic basement rocks exposed west of the suture.

Structural, stratigraphic and geochronological relations of the Bear Mountains ophiolitic melange and the Tuolumne ophiolitic melange will serve as the primary focus of this paper. The regional map patterns of these ophiolitic melange units are shown in Figure 1. More detailed maps which show the critical areas from which the age samples were taken are shown in Figures 2 and 3. The Tuolumne ophiolitic melange is exposed in the core area of a large south plunging anticline. The Penon Blanco volcanics, and younger volcaniclastic-slate sequences of the Mother Lode and western belts

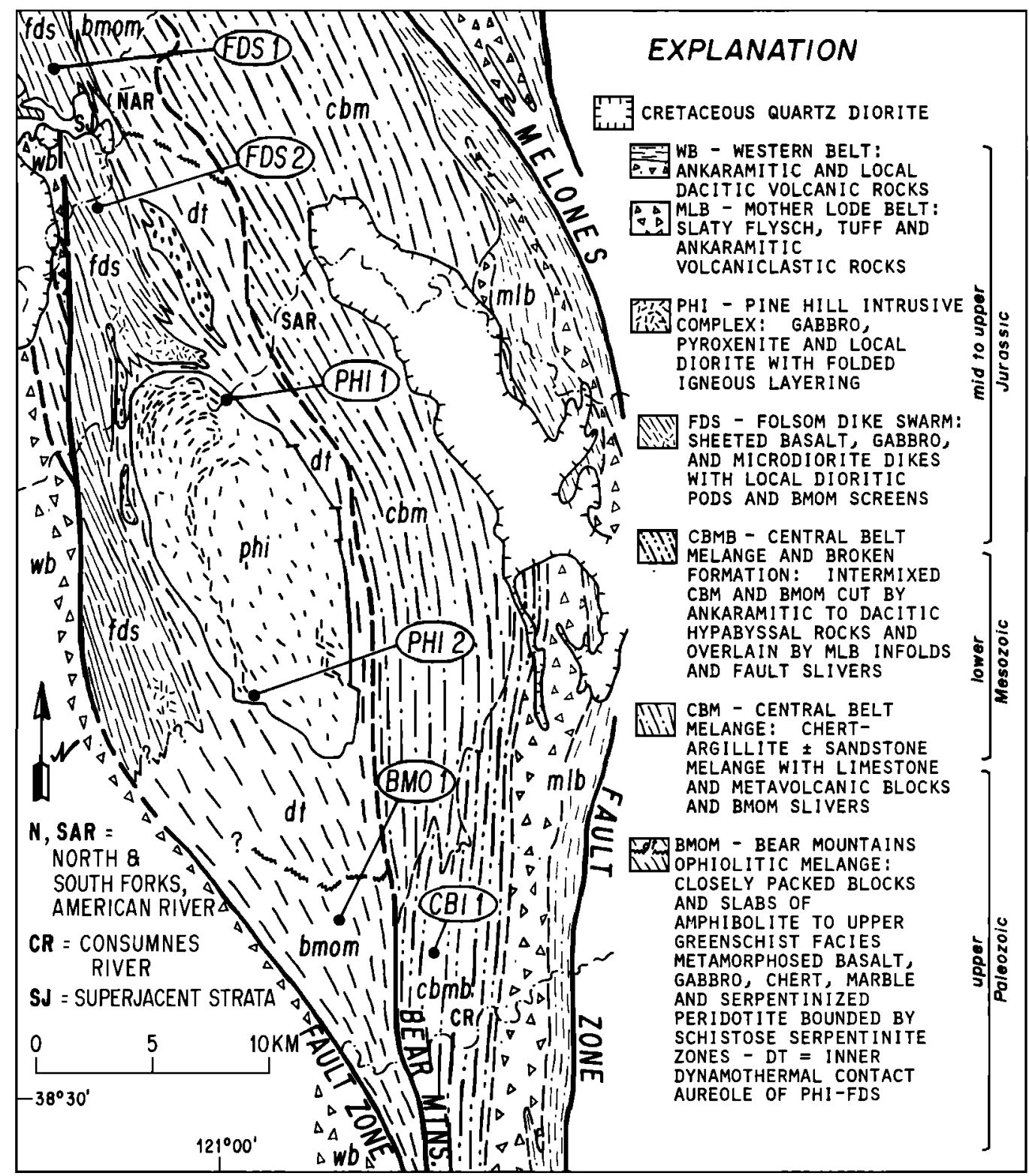

Fig. 2. Geologic map showing general setting of Bear Mountains ophiolitic melange and related rock units. Also shown are locations of zircon samples reported in Table 1. Geology after Olmstead [1971], Clark [1976], Behrman $[1978 a, b]$, Springer [1980b], and J. B. Saleeby and W. H. Wright III. 
successively envelope the ophiolitic basement core. A complex system of longitudinal faults which complicates the hinge area and western limb of the large anticline, extends northward from the Tuolumne region as the Bear Mountains fault zone.

The Bear Mountains fault zone is the locus of another anticlinal exposure of ophiolitic basement rock, the Bear Mountains melange (Figure 1). This ophiolitic melange is flanked on the west by the western volcaniclastic-slate belt, and is intermixed to the east with central belt melange which is in turn overlain and flanked on its east by the Mother Lode belt. Northward along the Bear Mountains melange sheeted dikes and layered gabbros of the $160 \mathrm{~m} . \mathrm{y}$. age group crosscut and contact metamorphose the older rocks. These intrusives are similar in age to the Smartville block and may be its southern extremity. If so it follows that the Bear Mountains belt may be the core of a very large north-plunging anticlinal structure that is enveloped by the Smartville block. Alternatively, the Smartville block may be a completely detatched thrust sheet lying structurally above the Bear Mountains belt and its cross-cutting sheeted dikes and gabbroic intrusives (E. M. Moores, personal communication, 1980). The field and geochronological aspects of such complexities are presently under investigation (E. M. Moores and J. Saleeby).

Ophiolitic rocks of the Kings-Kaweah segment of the belt bear strong similarities to those of the Tuolumne and Bear Mountains segments. The structure and geochronology of the Kings-Kaweah segment have been discussed in detail [Saleeby, 1978, 1979; Saleeby and Sharp, 1980]. Critical relationships from the Kings-Kaweah segment will be sum- marized and integrated with new data presented for the Tuolumne and Bear Mountains segment. Similar patterns in the geochronological data from each segment form a basis for regional stratigraphic and tectonic correlations. In the following section published and new geochronological data will be discussed and interfaced with the geological settings of the samples.

\section{Geochronological Framework of THE OPHIOLITE BELT}

New zircon $\mathrm{Pb} / \mathrm{U}$ age data on the Sierran ophiolite belt for six samples related to the Bear Mountains segment, five samples related to the Tuolumne segment, and two from the Kings-Kaweah segment are given in Table 1. Information on the sample locations and their zircon yield are given in Table 2 . In this section the zircon data are used in conjunction with the geological settings of the samples to develop a geochronological framework from which the petrogenetic and stratigraphic relations along the belt can be viewed. Additional hornblende $\mathrm{K} / \mathrm{Ar}$ data on ophiolitic mafic tectonites give valuable insight into the metamorphic and deformational history of the belt, particularly when integrated with the zircon data and with field and petrographic observations.

Inasmuch as metamorphic textures are widespread throughout the ophiolite belt, the possibility of open system behavior in the zircon $\mathrm{Pb} / \mathrm{U}$ systems is a critical issue. Open system behavior with episodic radiogenic $\mathrm{Pb}$-loss has been discussed by Wetherill [1956], Silver and Deutsch [1963], Davis et al. [1968], and Saleeby and Sharp [1980]. The mark of such behavior is a normal discordance pattern with the

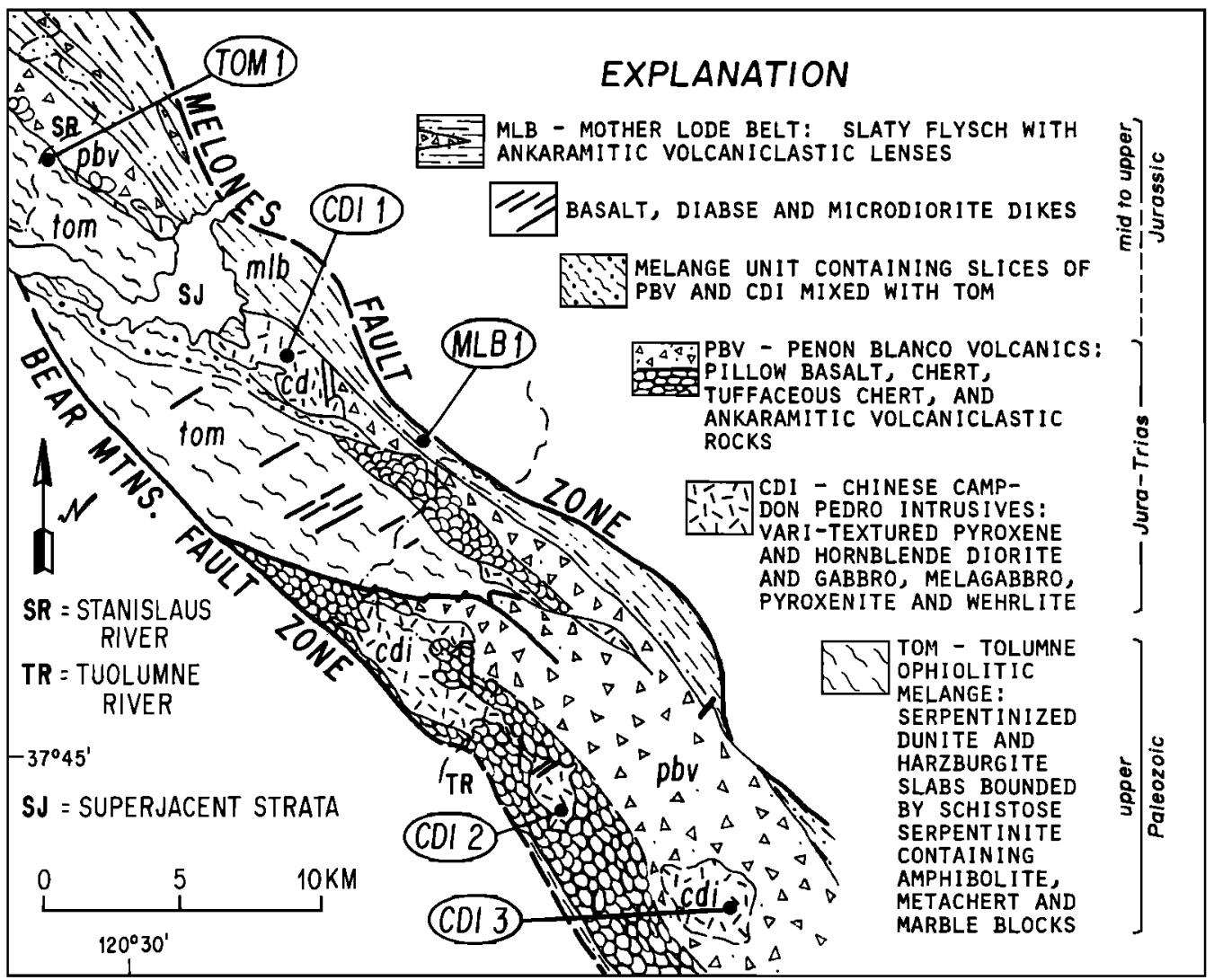

Fig. 3. Geologic map showing general setting of Tuolumne ophiolitic melange and related rock units. Also shown are locations of zircon samples reported in Table 1. Geology after Clark [1964], Morgan [1976], and J. B. Saleeby. 


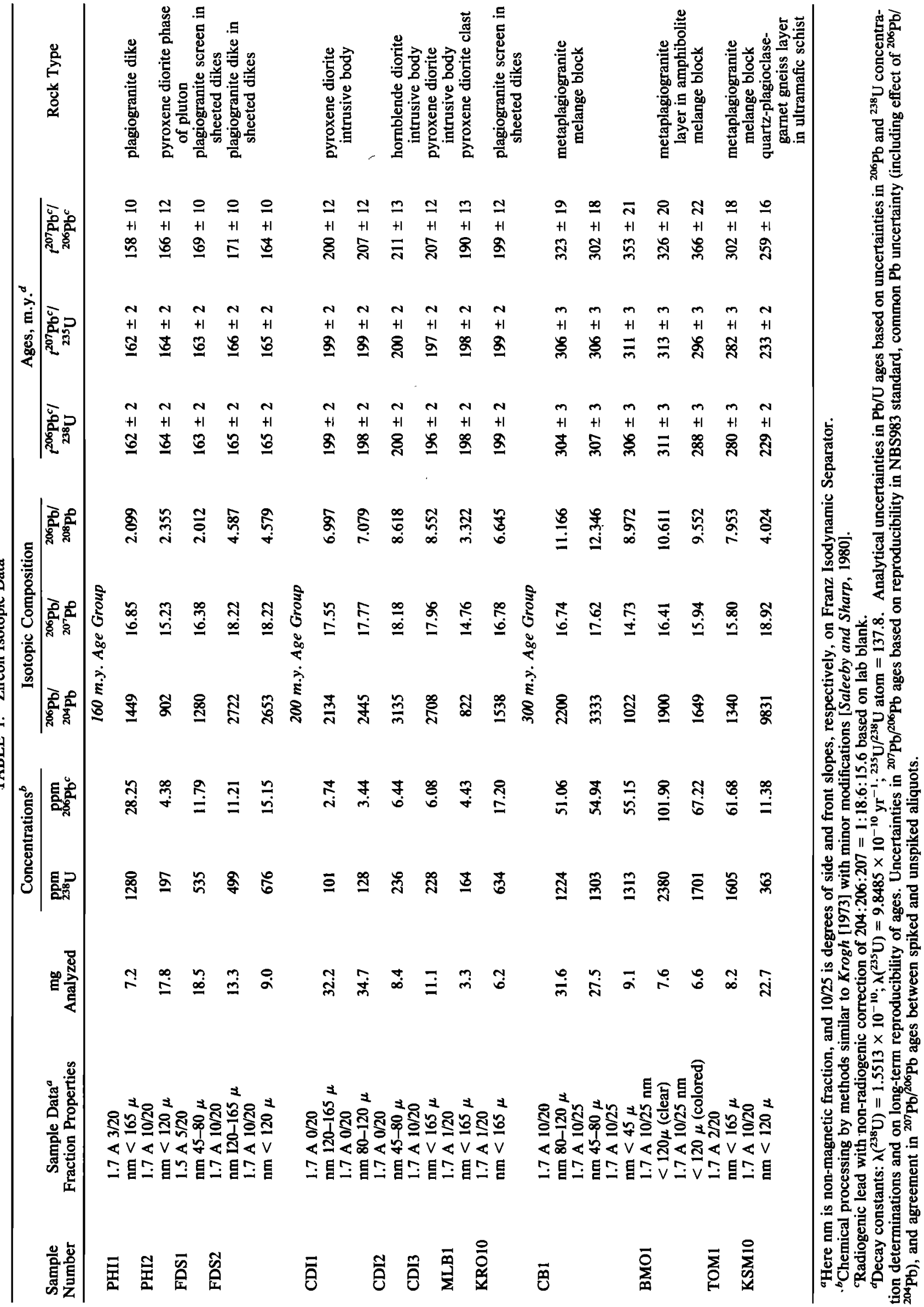


${ }^{206} \mathrm{~Pb} /{ }^{238} \mathrm{U}$ age less than the ${ }^{207} \mathrm{~Pb} /{ }^{235} \mathrm{U}$ age which is in turn less than the ${ }^{207} \mathrm{~Pb} /{ }^{206} \mathrm{~Pb}$ age. Closed system behavior is evidenced by concordance or the equivalence of these ages. However, in the age range under consideration, the analytical uncertainties of the ages are a major inhibiting factor in resolving whether a zircon analysis is concordant, or apparently concordant but in reality discordant.
Apparent concordance is defined as agreement of ages within analytical uncertainty. The analytical uncertainties for the zircon data are given in Table 1 along with a brief explanation of their derivation. Concordance within the systematics of a single zircon analysis is considered apparent because with zircon populations in the $300 \mathrm{~m}$.y. and younger age range a moderate yet geologically significant disturbance

TABLE 2. Data on Zircon Sample Location, Petrography, and Yield

\begin{tabular}{|c|c|c|c|c|}
\hline $\begin{array}{l}\text { Sample } \\
\text { Number* }\end{array}$ & Field Location & Field Setting & Petrography & $\begin{array}{l}\text { Zircon } \\
\text { Yield (mg)/ } \\
\text { Sample } \\
\text { Size (kg) }\end{array}$ \\
\hline $\begin{array}{l}\text { CB1 } \\
\text { (CB1) }\end{array}$ & $\begin{array}{l}\text { Fiddletown } 7.5^{\prime} \text { quad: } \\
\text { lat } 38^{\circ} 34^{\prime} 19^{\prime \prime} \mathrm{N} \\
\text { long } 120^{\circ} 52^{\prime} 26^{\prime \prime} \mathrm{W}\end{array}$ & $\begin{array}{l}\text { Creek bottom exposure of } \\
\text { monolithologic block in } \\
\text { sliver of serpentinite me- } \\
\text { lange }\end{array}$ & $\begin{array}{l}\text { Metaplagiogranite: partially granulated and fine- } \\
\text { ly recrystallized oligoclase and quartz, with } \\
\text { relict granophyric texture; accessory chlorite, } \\
\text { calcite, and sericite. }\end{array}$ & $85 / 104$ \\
\hline $\begin{array}{l}\text { BMO1 } \\
\text { (BMO1) }\end{array}$ & $\begin{array}{l}\text { Latrobe } 7.5^{\prime} \text { quad: } \\
\text { lat } 38^{\circ} 33^{\prime} 04^{\prime \prime} \mathrm{N}, \\
\text { long } 120^{\circ} 56^{\prime} 42^{\prime \prime} \mathrm{W}\end{array}$ & $\begin{array}{l}\text { Hilltop exposure of } 50 \mathrm{~m} \\
\text { thick concordant layer in } \\
\text { amphibolite tectonite }\end{array}$ & $\begin{array}{l}\text { Metaplagiogranite: almost completely recrystal- } \\
\text { lized quartz and Na-plagioclase with relict oli- } \\
\text { goclase igneous grains and accessory meta- } \\
\text { morphic green hornblende, epidote and } \\
\text { magnetite. }\end{array}$ & $15 / 109$ \\
\hline $\begin{array}{l}\text { TOM1 } \\
\text { (TO9) }\end{array}$ & $\begin{array}{l}\text { Melones Dam } 7.5^{\prime} \text { quad: } \\
\text { lat } 37^{\circ} 56^{\prime} 37^{\prime \prime} \mathrm{N}, \\
\text { long } 120^{\circ} 31^{\prime} 04^{\prime \prime} \mathrm{W}\end{array}$ & $\begin{array}{l}\text { Knobly exposure of } 10 \mathrm{~m} \\
\text { diameter monolithologic } \\
\text { block in serpentinite me- } \\
\text { lange }\end{array}$ & $\begin{array}{l}\text { Metaplagiogranite: granulated quartz and oligo- } \\
\text { clase with relict hypidiomorphic granular tex- } \\
\text { ture; secondary accessory chlorite and calcite. }\end{array}$ & $9 / 90$ \\
\hline $\begin{array}{l}\text { KSM10 } \\
(\mathrm{P} 12)\end{array}$ & $\begin{array}{l}\text { Piedra } 7.5^{\prime} \text { quad: } \\
\text { lat } 36^{\circ} 47^{\prime} 21^{\prime \prime} \mathrm{N}, \\
\text { long } 119^{\circ} 25^{\prime} 23^{\prime} \mathrm{W}\end{array}$ & $\begin{array}{l}\text { Concordant layer within ul- } \\
\text { tramafic schist }\end{array}$ & $\begin{array}{l}\text { Plagiogranite gneiss: gneissic banding defined by } \\
\text { model and grain-size variation in quartz, } \mathrm{Na-} \\
\text { plagioclase, garnet, and sphene with granob- } \\
\text { lastic epidote overprint. }\end{array}$ & $\sim 25 / 41$ \\
\hline $\begin{array}{l}\text { CDI1 } \\
(\mathrm{TO} 14)\end{array}$ & $\begin{array}{l}\text { Sonora } 7.5^{\prime} \text { quad: } \\
\text { lat } 37^{\circ} 52^{\prime} 36^{\prime \prime} \mathrm{N}, \\
\text { long } 120^{\circ} 26^{\prime} 24^{\prime \prime} \mathrm{W}\end{array}$ & $\begin{array}{l}\text { Road cut exposure in ho- } \\
\text { mogeneous diorite }\end{array}$ & $\begin{array}{l}\text { Pyroxene diorite: granulated and partly recrystal- } \\
\text { lized intermediate plagioclase with relict diop- } \\
\text { sidic augite grains, secondary chlorite, serpen- } \\
\text { tine, actinolite, epidote, and fine white mica. }\end{array}$ & $-250 / 88$ \\
\hline $\begin{array}{l}\text { CDI2 } \\
(\mathrm{TO} 11)\end{array}$ & $\begin{array}{l}\text { Penon Blanco Peak } 7.5^{\prime} \\
\text { quad: lat } 37^{\circ} 43^{\prime} 58^{\prime \prime} \mathrm{N} \\
\text { long } 120^{\circ} 19^{\prime} 37^{\prime \prime} \mathrm{W}\end{array}$ & $\begin{array}{l}\text { Hillside exposure of vari- } \\
\text { textured intrusive body }\end{array}$ & $\begin{array}{l}\text { Hornblende diorite: coarse brown-green horn- } \\
\text { blende and intermediate plagioclase in hypidio- } \\
\text { morphic granular texture, relict clinopyroxene } \\
\text { and secondary epidote, white mica, green am- } \\
\text { phibole, and quartz. }\end{array}$ & $\sim 150 / 86$ \\
\hline $\begin{array}{l}\text { CDI3 } \\
(\text { TO35) }\end{array}$ & $\begin{array}{l}\text { Penon Blanco Peak } 7.5^{\prime} \\
\text { quad: lat } 37^{\circ} 42^{\prime} 02^{\prime \prime} \mathrm{N} \\
\text { long } 120^{\circ} 16^{\prime} 04^{\prime \prime} \mathrm{W}\end{array}$ & $\begin{array}{l}\text { Road cut exposure in vari- } \\
\text { textured diorite }\end{array}$ & $\begin{array}{l}\text { Pyroxene diorite: highly recrystallized remnants } \\
\text { of hypidiomorphic texture with remnants of } \\
\text { clinopyroxene grains largely replaced by chlo- } \\
\text { rite-actinolite clusters. Plagioclase completely } \\
\text { altered to sericite, calcite, and albite. }\end{array}$ & $12 / 98$ \\
\hline $\begin{array}{l}\text { MLB1 } \\
(\mathrm{TO} 21)\end{array}$ & $\begin{array}{l}\text { Chinese Camp } 7.5^{\prime} \text { quad: } \\
\text { lat } 37^{\circ} 51^{\prime} 02^{\prime \prime} \mathrm{N}, \text { long } \\
120^{\circ} 23^{\prime} 39^{\prime \prime} \mathrm{W}\end{array}$ & $\begin{array}{l}\text { Cobble in conglomerate } \\
\text { bed exposed along road } \\
\text { cut }\end{array}$ & $\begin{array}{l}\text { Pyroxene diorite: granulated and recrystallized } \\
\text { intermediate plagioclase and clinopyroxene; } \\
\text { secondary epidote, chlorite, pumpellyite, and } \\
\text { white mica. }\end{array}$ & $3 / 6$ \\
\hline $\begin{array}{l}\text { KRO10 } \\
\text { (PF250) }\end{array}$ & $\begin{array}{l}\text { Pine Flat Dam } 7.5^{\prime} \text { quad: } \\
\text { lat } 36^{\circ} 46^{\prime} 33^{\prime \prime} \mathrm{N} \text {, long } \\
119^{\circ} 15^{\prime} 32^{\prime \prime} \mathrm{W}\end{array}$ & $\begin{array}{l}30 \mathrm{~cm} \text { wide screen in basal- } \\
\text { tic sheeted dikes at base } \\
\text { of cliff }\end{array}$ & $\begin{array}{l}\text { Metaplagiogranite: hornfelsic Na-plagioclase, } \\
\text { quartz, and minor green hornblende; relict } \\
\text { granophyric texture. }\end{array}$ & $6 / 74$ \\
\hline $\begin{array}{l}\text { FDS1 } \\
\text { (SV1) }\end{array}$ & $\begin{array}{l}\text { Auburn } 7.5^{\prime} \text { quad: } \\
\text { lat } 38^{\circ} 53^{\prime} 39^{\prime \prime} \mathrm{N}, \\
\text { long } 121^{\circ} 04^{\prime} 31^{\prime \prime} \mathrm{W}\end{array}$ & $\begin{array}{l}25 \mathrm{~cm} \text { wide screen in basal- } \\
\text { tic sheeted dikes along } \\
\text { road cut }\end{array}$ & $\begin{array}{l}\text { Plagiogranite/quartz diorite: fine-grained Na-pla- } \\
\text { gioclase, quartz and green amphibole with sec- } \\
\text { ondary epidote, chlorite, and fine white mica. }\end{array}$ & $18 / 81$ \\
\hline $\begin{array}{l}\text { FDS2 } \\
\text { (FD28B) }\end{array}$ & $\begin{array}{l}\text { Pilot Hill } 7.5^{\prime} \text { quad: } \\
\text { lat } 38^{\circ} 50^{\prime} 32^{\prime} ' \mathrm{~N}, \\
\text { long } 121^{\circ} 04^{\prime} 03^{\prime \prime} \mathrm{W}\end{array}$ & $\begin{array}{l}\text { Boudinaged dike in de- } \\
\text { formed mafic sheeted } \\
\text { dikes }\end{array}$ & $\begin{array}{l}\text { Plagiogranite: distorted and recrystallized grains } \\
\text { of quartz and Na-plagioclase with granoblastic } \\
\text { chlorite and actinolite. }\end{array}$ & $\sim 30 / 89$ \\
\hline $\begin{array}{l}\text { PHI } \\
\text { (PH2) }\end{array}$ & $\begin{array}{l}\text { Coloma } 7.5^{\prime} \text { quad: } \\
\text { lat } 38^{\circ} 46^{\prime} 07^{\prime \prime} \mathrm{N} \\
\text { long } 121^{\circ} 00^{\prime} 00^{\prime \prime} \mathrm{W}\end{array}$ & $\begin{array}{l}10 \mathrm{~cm} \text { wide deformed dike } \\
\text { within gabbro host along } \\
\text { stream gorge }\end{array}$ & $\begin{array}{l}\text { Plagiogranite: coarse-grained hypidiomorphic } \\
\text { granular intermediate plagioclase quartz and } \\
\text { hornblende with incipient recrystallization with } \\
\text { sparce epidote and chlorite. }\end{array}$ & $7 / 70$ \\
\hline $\begin{array}{l}\text { PHI2 } \\
\text { (PH10) }\end{array}$ & $\begin{array}{l}\text { Shingle Springs } 7.5^{\prime} \text { quad: } \\
\text { lat } 38^{\circ} 38^{\prime} 57^{\prime \prime} \mathrm{N} \text {, long } \\
120^{\circ} 58^{\prime} 32^{\prime \prime} \mathrm{W}\end{array}$ & $\begin{array}{l}\text { Low-color index phase of } \\
\text { mixed zone in pluton }\end{array}$ & $\begin{array}{l}\text { Pyroxene diorite: hypidiomorphic granular clino- } \\
\text { pyroxene and intermediate plagioclase, minor } \\
\text { orthopyroxene, deep red biotite and magnetite, } \\
\text { trace quartz. }\end{array}$ & $18 / 75$ \\
\hline
\end{tabular}

*Original field number in parentheses. 
disperses the ages only within a range comparable to that of the analytical uncertainty. Thus additional criteria are needed for the recognition of true concordance.

The analysis of multiple zircon fractions split from a cogenetic population based on physical properties such as size, shape, color and magnetic susceptability is helpful in resolving apparent from true concordance. Open system behavior within a cogenetic zircon population having a wide range of physical properties should result in a noticeable dispersion of ages between fractions, particularly the ${ }^{206} \mathrm{~Pb} /{ }^{238} \mathrm{U}$ ages which are the most precisely determined [Silver, 1963, 1964, 1969; Silver and Deutsch, 1963; Saleeby and Sharp, 1980]. Thus concordance within analytical uncertainty of ${ }^{206} \mathrm{~Pb} /{ }^{238} \mathrm{U}$ ages between multiple fractions is an important criterion for recognizing true concordance.

An additional criterion for the recognition of true concordance is the analysis of zircon populations from different locations within a cogenetic suite of rocks. Except for the case of complete resetting, at least a moderate dispersion of ages, partichlarly ${ }^{206} \mathrm{~Pb} /{ }^{38} \mathrm{U}$ ages, should be recognizable throughout a large rock body in the event of an episodic disturbance. Further insight into zircon behavior is also derived from geological observations including stratigraphic relations, metamorphic mineral assemblages and basic field relations.

By the use of all the criteria outlined above assumptions can be made about the behavior of the zircon for which data are given in Table 1. From these data igneous age constraints can be deduced. In the case of discordant populations only broad age constraints can be made, but there are a significant number of concordant ages for which tight constraints can be made. Viewing the concordant and discordant ages together in a context which includes the $\mathrm{K} / \mathrm{Ar}$ and geological data results in a coherent and geologically sound picture for the geochronological development of the Sierran ophiolite belt.

Isotopic age data for ophiolitic rocks of central and southern Sierra are graphically summarized in Figure 4. The ${ }^{206} \mathrm{~Pb} /{ }^{38} \mathrm{U}$ and ${ }^{207} \mathrm{~Pb} /{ }^{206} \mathrm{~Pb}$ ages are shown for each zircon analysis. The analytical uncertainties in the ${ }^{207} \mathrm{~Pb} /{ }^{206} \mathrm{~Pb}$ ages are shown by thick lies; overlap with the large points which symbolize the ${ }^{206} \mathrm{~Pb} /{ }^{238} \mathrm{U}$ ages indicates apparent concordance. The age data in Figure 4 are divided into four groups based on field locations. The data for each location are arranged into age groups which correspond to structuralstratigraphic sequences. Relations between sequences for which a relative chronology can be derived, such as unconformities or intrusive contacts, are also symbolized in Figure 4. Hornblende $\mathrm{K} / \mathrm{Ar}$ data on ophiolitic amphibolites are also summarized in Figure 4. Zircon ages on samples related to the ophiolite belt fall into three groups, 300, 200 and $160 \mathrm{~m}$.y. The $300 \mathrm{~m}$.y. group includes a number of discordant samples, and thus it can only be broadly defined. The younger groups are more tightly defined in that they yield predominantly concordant ages. Discussion of the age data will begin with the $160 \mathrm{~m}$.y. group inasmuch as this group has experienced a simple metamorphic history relative to the other two groups.

\section{0 m.y. Age Group}

Zircon ages in the $160 \mathrm{~m} . \mathrm{y}$. range have been determined for rocks of the Pine Hill intrusive complex and the Folsom Lake dike swarm (Figure 2). Note that the sample numbers have been coded by letter prefixes for easy referencing between Table 1 and the geologic maps and diagrams. The Pine Hill intrusive complex has been studied in detail by Springer $[1980 a, b]$, and the Folsom dike swarm has been mapped by Olmstead [1971] and J. Saleeby, W. H. Wright III and R. K. Springer (ongoing field studies). The Pine Hill complex consists of a main layered intrusive body composed of gabbro with lesser clinopyroxenite and diorite, and smaller massive satellitic intrusives with a similar compositional range. The Folsom dike swarm consists of basalt, gabbro, diorite and rare plagiograite dikes with large sheeted domains.

The Pine Hill complex and the Folsom dike swarm are intruded into the northern end of the Bear Mountains ophiolitic melange. A narrow screen of the melange separates the Pine Hill complex from the dike swarm, and a number of similar screens occur within the dike swarm. A wide range of wallrock compositions, which include ultramafic, mafic and carbonate assemblages, display hornblende hornfels to pyroxene hornfels facies mineral assemblages [Springer, 1974, 1980a, b]. As discussed below, however, the contact metamorphic fabrics are largely tectonitic related to synplutonic and hot sub-solidus deformation in the Pine Hill and Folsom intrusives.

Zircon data on the Pine Hill complex include a $162 \mathrm{~m} . \mathrm{y}$. concordant age on a late-stage plagiogranite dike (PHI1), and a $164 \mathrm{~m}$.y. concordant age on a pyroxene diorite phase of the main plutonic mass (PHI2). Concordant ages are given in the text as rounded off ${ }^{206} \mathrm{~Pb} /{ }^{238} \mathrm{U}$ ages. Similar concordant ages were obtained for the Folsom dike swarm. Sample FDS1 is from a plagiogranite screen within sheeted basaltic dikes; its age is $163 \mathrm{~m} . \mathrm{y}$. Sample FDS2 yields $165 \mathrm{~m} . \mathrm{y}$. concordant ages within and between multiple fractions. This sample is from a boudinaged plagiogranite dike which lies concordantly within deformed mafic sheeted dikes.

Zircon ages reported above for the Pine Hill intrusive complex and the Folsom dike swarm are considered reasonable igneous age determinations. This is supported by unanimity of apparent concordance, tight agreement of ages over a wide geographic range, and concordance between multiple fractions of sample FDS2. Furthermore, regional amphibolite and greenschist facies tectonites of the Bear Mountains ophiolitic melange show a resetting of their $\mathrm{K} / \mathrm{Ar}$ hornblende systems to a reasonable age range within the aureole of the Pine Hill intrusive complex and the adjacent Folsom dike swarm (Figures 2 and 4).

A common concern in using plagiogranites to date ophiolitic assemblages is whether the subordinate felsic rocks significantly post-date the mafic igneous sequence. In the case of the Folsom dike swarm sample FDS1 is from a screen which is cut by the mafic dikes. Furthermore, sample FDS2 is from a domain of sheeted dikes which shows strong protoclastic deformation, and such deformation is shared by the plagiogranite as well as the predominate mafic dikes. Protoclastic deformation in the dike swarm consists of widespread boudinage, homogeneous flattening, streaking out and local folding of dikes. Contradictory relations between deformation features and intrusive contacts indicate a protoclastic or synplutonic deformational regime. Protoclastic deformation features are also widespread in the Pine Hill complex [Springer, 1980a, b]. Of importance with respect to the age data is the presence of local masses of plagiogranite that were mobile during such deformation along with remobilized cumulate-textured pyroxenite and gabbro. This indi- 


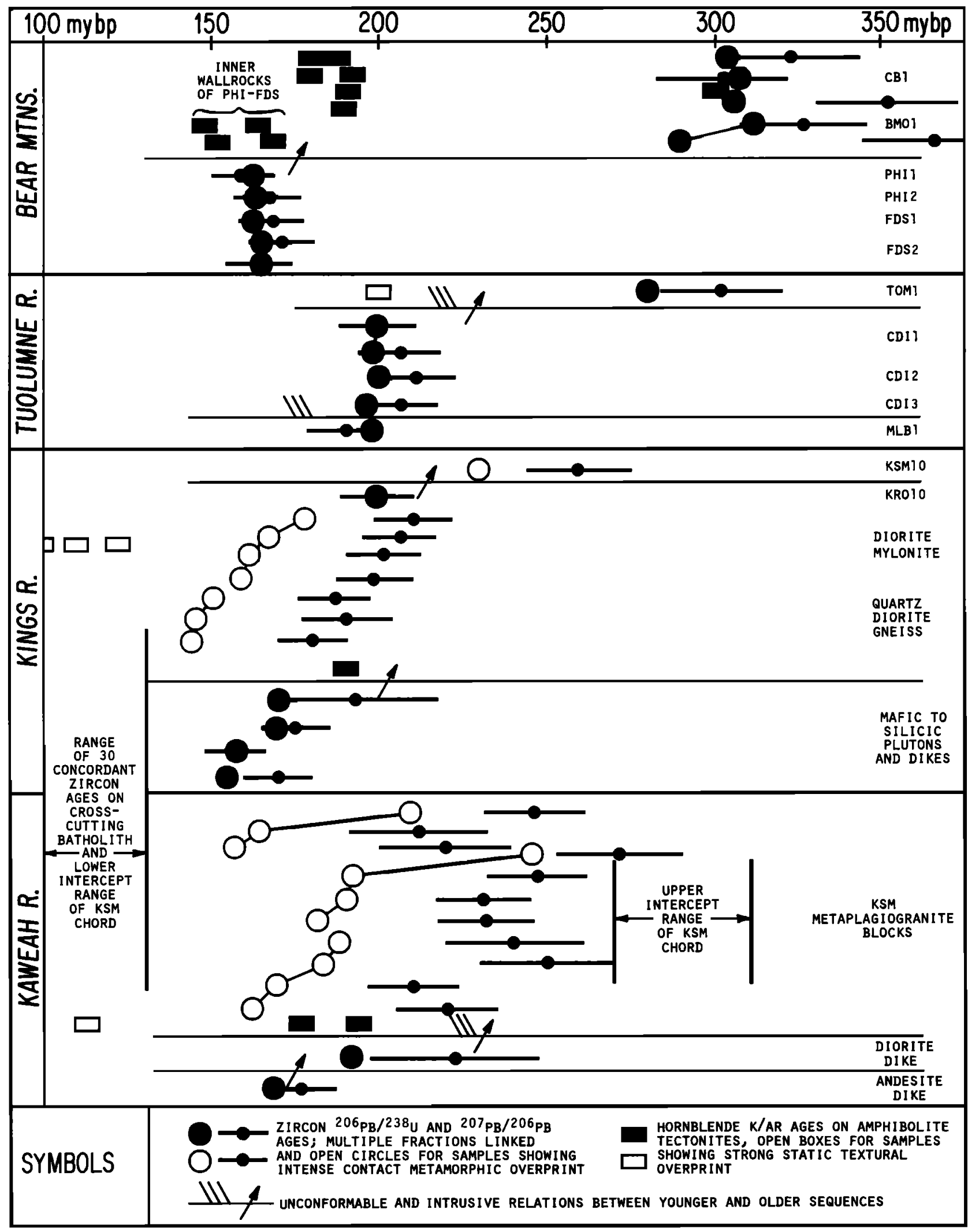

Fig. 4. Summary of geochronological data for central and southem segments of Sierra Nevada opholite belt. Sample numbers are given for zircon data reported in this paper. Additional zircon data from Saleeby and Sharp [1980], Chen and Moore [1982]. K/Ar homblende data on mafic tectonites from Morgan [1976], Behrman [1978a, b], Saleeby and Sharp [1980], and J. B. Saleeby and L. A. Silver (work in progress). 
cates co-magmatic relations between the plagiogranite and the main mass of the pluton as suggested by the near equivalence of ages between the PHI1 plagiogranite and PHI2 pyroxene diorite. The age data along with the geological relations show that the Pine Hill intrusive complex and the Folsom dike swarm were magmatically emplaced into the Bear Mountains ophiolitic melange between 163 and 165 m.y.

Igneous assemblages with roughly comparable zircon ages occur in association with the Kings-Kaweah segment of the belt (Figure 4 and Saleeby and Sharp [1980]). Such igneous rocks include plutonic bodies of dioritic to pyroxenitic composition, with gross similarities to the Pine Hill complex, and a homogeneous quartz diorite which crosscuts the dioritic to pyroxenitic body. Zircon ages with apparent concordance of $170 \mathrm{~m} . \mathrm{y}$. and 157 m.y., respectively, have been determined on these bodies. Additional Middle to Upper Jurassic ages have been determined on plagiogranite and andesitic dikes which cross-cut ophiolitic rocks and which occur in association with volcaniclastic strata that lie unconformably above ophiolitic melange.

Zircon ages in the 155 to 170 m.y. range from the KingsKaweah region, and the 163 to 165 m.y. ages from the Pine Hill-Folsom association are collectively referred to as midto Late Jurassic in later stratigraphic discussions. Peridotitic to dioritic intrusive complexes and a regional swarm of mafic dikes which yield numerous $\mathrm{Pb} / \mathrm{U}$ and $\mathrm{K} / \mathrm{Ar}$ ages in the 170 to $157 \mathrm{~m} . \mathrm{y}$. range cut the Calaveras Complex and adjacent continental margin assemblage east of the Foothills suture [Sharp and Saleeby, 1979; Sharp, 1980]. The mafic dikes also cut ophiolitic melange and 200 m.y. rocks exposed along the Tuolumne segment of the belt. Thus the entire central and southern Sierra foothill region was the site of igneous activity involving the emplacement of ultramafic to dioritic plutons and widespread emplacement of primarily mafic composition dikes in mid- to Late Jurassic time. The igneous age of the Smartville ophiolite falls within this age group [Saleeby et al., 1979], and as discussed below stratigraphic and paleontological data constrain most volcaniclastic-slate sequences to a similar age.

\section{0 m.y. Age Group}

Zircon ages in the $200 \mathrm{~m}$.y. range have been determined for rocks of the Chinese Camp-Don Pedro intrusive complex along the Tuolumne segment of the belt (Figure 3). The area between samples CDI1 and 2 was mapped by Morgan [1976]. Topical mapping within this area and its extensions to the northwest and southeast was done in conjunction with this study. The Chinese Camp-Don Pedro intrusives are considered to be the shallow-level feeder system for the Penon Blanco volcanics which lie unconformably above the Tuolumne ophiolitic melange (B. A. Morgan, personal communication, 1976). Field and petrographic data obtained in this study strongly support Morgan's interpretation.

The Chinese Camp-Don Pedro intrusive complex consists primarily of vari-textured pyroxene and hornblende diorite with subordinate amounts of wehrlite, clinopyroxenite and gabbro. Three of five dioritic members sampled yielded zircon. Sample CDIl is a pyroxene diorite which has yielded concordant ages of 199 m.y. within and between multiple fractions. Similar single fraction concordant ages of 200 and $196 \mathrm{~m} . y$. were determined on a hornblende diorite (CDI2) and another pyroxene diorite (CDI3) respectively. A large cobble-size clast of Chinese Camp-Don Pedro-like pyroxene diorite from the overlying Mother Lode flysch sequence also yields a concordant age of 198 m.y. (MLB1).

In a regional study of $\mathrm{K} / \mathrm{Ar}$ systematics, W. D. Sharp (personal communication, 1980) obtained a $200 \mathrm{~m}$.y. igneous hornblende age on sample CDI2. Furthermore, Morgan [1976] reports a $200 \pm 10 \mathrm{~m}$.y. igneous hornblende age from Chinese Camp-Don Pedro wehrlite. A $200 \pm 10$ m.y. amphibole age is also reported by Morgan [1976], on a garnet amphibolite block from the Tuolumne ophiolitic melange. The amphibolite block shows a pervasive static-textured green amphibole overprint. Static-textured overprints are also common in the ultramafic rocks of the Tuolume ophiolitic melange as well as in mafic, chert, carbonate and plagiogranite melange blocks. Contact relations between the main exposures of the Chinese Camp-Don Pedro intrusives and the Tuolumne ophiolitic melange are obscured by Jurassic deformation. However, disrupted dikes of Chinese Camp-Don Pedro gabbro and diorite cross-cut the basement, and the widespread static-textured overprint in the basement has no apparent source other than heat related to the intrusive complex.

Concordance of ages within and between zircon fractions, consistency of ages from different sample locations, and agreement with the $\mathrm{K} / \mathrm{Ar}$ data all indicate an igneous age of about 200 m.y. for the Chinese Camp-Don Pedro complex. Field and petrologic data which show that such an age is applicable for the Penon Blanco volcanics are discussed with the stratigraphic relations.

Rocks in the 200 m.y. range also constitute an important component of the Kings-Kaweah segment. Sample KR010 from the Kings River ophiolite yields a 199 m.y. zircon age with apparent concordance. A poor zircon yield prohibited multiple fraction analysis. Sample KR010 is from a plagiogranite screen within a sheeted dike sequence. The dike sequence lies beneath pillow basalt and above gabbro and ultramafic-mafic tectonite which together constitute a complete ophiolite section [Saleeby, 1978].

Prior to the age determination on KR010 an approximate $200 \mathrm{~m} . y$. age was interpreted for the Kings River section based on discordant zircon ages, $\mathrm{K} / \mathrm{Ar}$ data and geological relations. Discordant age arrays from diorite mylonite and quartz diorite gneiss layers present in the lower levels of the ophiolite are shown in Figure 4. The diorite mylonite layer occurs as a thin segregation in protoclastically deformed gabbro which itself is encased in dunite-harzburgitic tectonite. The ultramafic tectonites also encase a layer of coarsely banded leucoquartz diorite and diorite gneiss from which the quartz diorite fraction was sampled. Unfortunately the rare zircon-bearing dioritic layers lie within the metasomatic contact aureole of a cross-cutting Cretaceous pluton. Zircon samples from such field settings along the entire length of the Kings-Kaweah segment show episodic Pb-loss due to hydrothermal attack during contact metamorphism. $\mathrm{K} / \mathrm{Ar}$ ages from the amphibolitic gabbro host of the diorite mylonite layer and similar amphibolitic rocks within the aureole are completely reset to Cretaceous ages (Figure 4). Comparison of the zircon systematics and hydrothermal attack effects between the Kings River diorites and more discordant plagiogranite zircon from Kaweah melange blocks led $\mathrm{Sa}$ leeby and Sharp [1980] to conclude a relatively moderate disturbance for the diorite zircon populations and thus a Jura-Trias or approximate $\mathbf{2 0 0} \mathrm{m}$.y. igneous age. This inter- 
pretation is further supported by a $190 \mathrm{~m} . \mathrm{y} . \mathrm{K} / \mathrm{Ar}$ age on igneous hornblende from a protoclastically deformed amphibolitic gabbro layer located well outside the Cretaceous contact aureole [Saleeby and Sharp, 1980].

Ophiolitic melange of the Kaweah River area is unconformably overlain by a volcanic-chert sequence which is similar to the Penon Blanco volcanics of the Tuolumne segment. This sequence is in turn unconformably overlain by a volcaniclastic-slate assemblage with strong similarities to the Mother Lode belt, which in the Tuolumne region lies above the Penon Blanco volcanics. Thus regional stratigraphic relations suggest a Jura-Trias age for the Kaweah volcanic-chert sequence. Mafic dikes which cut the ophiolitic melange basement and extend up into the volcanics appear to be the volcanic feeder system. A dioritic dike rock associated with this system yields a slightly discordant zircon age in the 200 m.y. range (Figure 4 and Saleeby and Sharp [1980]). Poor zircon yield again prohibited multiple fraction analysis. The slight discordance, weak metamorphic features in the diorite and stratigraphic relations all support an age assignment of about $200 \mathrm{~m} . \mathrm{y}$. for the diorite and its associated mafic dikes.

From the above discussion of age data and geological relations a $200 \mathrm{~m}$.y. age group can be tightly defined along the Tuolumne segment of the belt. Such rocks consist of a volcano-plutonic complex built on an ophiolitic melange basement. Along the Kings-Kaweah segment this age group is more loosely defined as rocks in the $200 \mathrm{~m}$.y. or Jura-Trias range which occur as a complete ophiolite sequence, and as mafic volcanic-hypabyssal rocks and chert also built on an ophiolitic melange basement. Zircon ages in this age range have not been obtained on rocks of the Bear Mountains segment. However, central belt melange rocks (Figures 1 and 2), which include elements of the Bear Mountains ophiolitic melange, contain large fault-bounded slabs of dioritic and mafic hypabyssal rock in sequence with a volcanic-chert section. Field and preliminary geochronological studies indicate a Jura-Trias age for such slabs (W. H. Wright III and J. Saleeby).

\section{0 m.y. Age Group}

Field settings of samples from the $300 \mathrm{~m} . \mathrm{y}$. age group are distinctly different from those of the younger groups which are from intact igneous bodies and stratigraphic sequences. All $300 \mathrm{~m} . \mathrm{y}$. samples are from plagiogranite bodies that occur as metamorphosed melange blocks or as layers within amphibolitic melange blocks. The zircon populations from the $300 \mathrm{~m}$.y. group are also distinctly different from those of the younger groups. Variable and high $U$ concentrations, deep coloring, crystal surface defects, and complex discordance patterns are common in the older rocks, but almost absent in the younger rocks (Table 1, Figure 4, and Saleeby and Sharp [1980]). Samples CB1 and BM01 yield the only zircon populations from the $300 \mathrm{~m}$.y. group with any semblance of concordance. These samples are from the Bear Mountains segment of the belt where blocks and slabs of ophiolitic material are densely packed with narrow intervening serpentinite matrix zones and where ophiolitic melange zones extend into central belt melange.

Sample CB1 is from a monolithologic block within a central belt serpentinite melange sliver. Sample BM01 is from a structurally concordant layer within one of the larger amphibolite slabs of the Bear Mountains melange. Sample
CB1 was split into three size fractions, whereas the poorer and overall finer grain-size yield of BM01 was hand sorted into deeply colored and relatively clear fractions.

The two coarser fractions of CB1 and the BM01 clear fraction yield concordant ages in the 304 to $311 \mathrm{~m}$.y. range (Table 1, Figure 4). The deeply colored BM01 fraction is significantly discordant, and the fine CB1 fraction is moderately discordant within its own systematics but has its ${ }^{206} \mathrm{~Pb} /{ }^{238} \mathrm{U}$ age in agreement with the other concordant fractions. The CB1 fine fraction is similar to the BM01 dark fraction in that both are deeply colored and include an abundance of poorly faceted grains with cracks and surface defects, and both contain numerous inclusions and rare darkened core areas. Such features may help explain preferential disturbance of the $\mathrm{Pb} / \mathrm{U}$ systematics, but the perplexing aspect of the discordances are the older ${ }^{207} \mathrm{~Pb} /{ }^{206} \mathrm{~Pb}$ ages.

Two alternative explanations are offered for the aberrant ${ }^{207} \mathrm{~Pb} /{ }^{206} \mathrm{~Pb}$ ages.

1. Impurities introduced into the darker zircon fractions at the time of crystallization included $\mathrm{Pb}$ which cannot be properly accounted for by the common $\mathrm{Pb}$ correction used (Table 1). Such initial $\mathrm{Pb}$ would have to be radiogenicenriched inasmuch as high ${ }^{206} \mathrm{~Pb} /{ }^{204} \mathrm{~Pb}$ ratios (1313 and 1701) were measured on the discordant fractions. The error would have a significant effect on the ${ }^{207} \mathrm{~Pb} /{ }^{206} \mathrm{~Pb}$ ages, but only a minor effect on the ${ }^{206} \mathrm{~Pb} /{ }^{238} \mathrm{U}$ ages. Furthermore, such an error would not be introduced into the systematics of the concordant fractions which lack the impurities.

2. Rare grains with darkened core areas reflect inheritance of older U-rich zircon which introduced old ${ }^{207} \mathrm{~Pb} /{ }^{206} \mathrm{~Pb}$ ages into the systematics. Either interpretation given above is difficult to reconcile with an idealized ridgecrest model for the generation of the ophiolitic protolith, and implies a multi-stage history for the $300 \mathrm{~m} . \mathrm{y}$. assemblage. Such early-stage complexities are further suggested by the $300 \mathrm{~m}$.y. K/Ar age obtained on an amphibolite tectonite slab from an ophiolitic melange exposure in the central belt [Behrman, 1978a, b]. Furthermore, both the CB1 and BM01 zircon populations are U-enriched relative to well-studied ophiolite sections [Mattinson, 1975, 1976; Hopson et al., 1980; Tilton et al., 1981]. Such a problem exists for zircon from other plagiogranite blocks, and suggests the presence of magma bodies that are U-enriched relative to typical midocean ridge basalt.

The concordant ages on CB1 and BM01 fractions which do not appear to have chemical and morphological complexities leads to the interpretation of these ages being igneous in origin. Whether this igneous event represents sea-floor spreading generation of an ophiolitic protolith or some other oceanic igneous process is irresolvable owing to the structural and metamorphic state of the rocks sampled. The younger ${ }^{206} \mathrm{~Pb} /{ }^{238} \mathrm{U}$ age in the $\mathrm{BM} 01$ colored fraction may reflect $\mathrm{Pb}$ loss in imperfect grains during Mesozoic metamorphic episodes.

Serpentinite melange exposures of the Tuolumne segment (Figure 3) also contain a plagiogranite melange block (Sample TOM1). The block is situated in an area which lacks obvious high grade metamorphic features. The only metamorphic features displayed in the plagiogranite are intense tectonic granulation and a low-greenschist facies static textured overprint. This overprint is attributed to the thermal event related to the Chinese Camp-Don Pedro intrusive complex. Sample TOM1 produced a poor zircon yield pro- 
hibiting multiple fraction analyses. Fortunately the population is quite homogeneous with a predominance of clear euhedral grains having smooth generally well-developed faces and terminations. Analysis of the total population yields slightly discordant ages in the $300 \mathrm{~m}$.y. range (Table 1 , Figure 4). Characteristics discussed above and in the work by Saleeby and Sharp [1980] which would suggest inheritance of older radiogenic $\mathrm{Pb}$ or significant episodic $\mathrm{Pb}$-loss are lacking. Thus minor Pb-loss is favored for the discordance mechanism of sample TOM1 and a primary age in the $300 \mathrm{~m} . \mathrm{y}$. range is most reasonable.

Plagiogranite occurs in blocks within serpentinite melange at several localities along the Kings-Kaweah segment of the belt (Figure 1). The ophiolite belt in this region has undergone a near penetrative hornblende hornfels facies metamorphism which was imparted by early Cretaceous plutonism of the Sierra Nevada batholith [Saleeby and Sharp, 1980]. Contact metamorphism of the serpentinite matrix gave rise to a complex family of metamorphic and metasomatic rocks, including antigorite and talc hornfels and jasper-magnesite skarns. Zircon populations from eight metaplagiogranite bodies encased within the metaserpentinites show a complex pattern in chemical attack and alteration and a wide range of discordant ages. The chemical activity of the contact metamorphic and metasomatic environment, in addition to high temperatures, is cited for the cause of the zircon disturbance [Saleeby and Sharp, 1980].

New zircon $\mathrm{Pb} / \mathrm{U}$ data are presented for one such sample (KSM10) in Table 1. This sample is from a quartz-plagioclase-garnet gneiss layer within ultramafic schist. The ultramafic schist bounds the western edge of the Kings River ophiolite and actually extends into the ultramafic-mafic tectonite portion of the ophiolite as screen-like bodies [ $\mathrm{Sa}$ leeby, 1978]. The protolith of the schist and its inclusions is the northern end of the Kaweah serpentinite melange. Much of the melange assemblage in the Kings River area has been polymetamorphosed, first by dynamothermal processes related to the Jura-Trias igneous history of the Kings River ophiolite, and then by contact metamorphic processes related to the Cretaceous batholith. The dynamothermal event will be discussed in the next section. The results of the contact metamorphic event are a static-textured talc overprint and patchy development of jasper-magnesite skarn in the ultramafic schist. The KSM10 felsic geniss shows granoblastic growth of epidote minerals related to the contact event, but the older gneissic fabric derived from the dynamothermal event is well-preserved.

Sample KSM10 exhibits a discordance pattern that is comparable to the discordance patterns of multiple fractions from three meta-plagiogranite melange blocks located further south along the Kaweah River (Figure 4 and Saleeby and Sharp [1980]). Not all metaplagiogranite samples of the Kings-Kaweah segment are represented in Figure 4. Those omitted have extremely high $U$ concentrations (up to 3400 ppm), show extreme surface defects, and have undergone late-stage and/or modern disturbances. Samples included in Figure 4 do not fall into such a category. Nevertheless, these samples still display significant discordances both within and between multiple fractions.

The eleven fractions shown in Figure 4 from the Kaweah melange define a tight best fit chord on a ${ }^{206} \mathrm{~Pb} /{ }^{238} \mathrm{U}-$ ${ }^{207} \mathrm{~Pb} /{ }^{35} \mathrm{U}$ concordia diagram. An early Cretaceous lower intercept for the chord coincides with the range of numerous concordant zircon ages measured on batholithic rocks responsible for the contact metamorphic episode [Saleeby and Sharp, 1980; Chen and Moore, 1982]. The upper intercept range is 270 to $310 \mathrm{~m}$.y. which is similar to concordant or near concordant ages measured on similar plagiogranites from the Tuolumne and Bear Moutains segments of the belt. Rocks of these northern segments did not experience Cretaceous contact metamorphism. A straightforward interpretation of the concordia data is an igneous age in the $300 \mathrm{~m} . \mathrm{y}$. range and episodic $\mathrm{Pb}$-loss during Cretaceous batholith emplacement. Zircon data from the KSM10 felsic gneiss layer fall on the same chord, and an approximate $300 \mathrm{~m}$.y. protolith age is interpreted for all such felsic layers and blocks within the Kaweah ophiolitic melange.

Discordant zircon systematics from Kings-Kaweah dioritic samples that are interpreted as about $200 \mathrm{~m}$.y. in age can be contrasted with those from the $300 \mathrm{~m} . \mathrm{y}$. plagiogranite blocks. The dioritic zircon data as a group are slightly offset to the high side of the plagiogranite chord. This relation translates into the Figure 4 plot as a more consistent and restricted dispersion in the ${ }^{206} \mathrm{~Pb} /{ }^{238} \mathrm{U}$ and ${ }^{207} \mathrm{~Pb} /{ }^{206} \mathrm{~Pb}$ ages. Inspection of Figure 4 also shows the dioritic fractions clustering in younger groups of ages than the plagiogranite fractions.

Zircon data on metaplagiogranite from melange blocks scattered along the entire $375 \mathrm{~km}$ length of the ophiolite belt consistently indicate igneous ages in the $300 \mathrm{~m} . \mathrm{y}$. range. Such felsic bodies occur as monolithologic blocks, as screens within blocks of mafic dike complex, and as structurally concordant layers within mafic tectonite blocks and ultramafic schist. The predominant block assortment consists of ultramafic and mafic tectonites, metachert and marble. Locally preserved protolith features such as pillows, sheeted dikes and radiolaria tests in bedded chert indicate the melange was derived from a complete ophiolite suite. The added presence of thick carbonate buildups on massive and vesicular basaltic flows indicates that seamount-type assemblages were closely associated with the ophiolitic fragments. The presence of seamount assemblages offers an explanation for possible multi-stage igneous processes and the presence of magma that may differ from mid-ocean ridge basalt. Other oceanic environments that may offer such complexities along with the early development of metamorphic tectonites are large fracture zones. The important point here is that the plagiogranite blocks are part of a complex ocean floor association. Chert and upper Paleozoic limestone sequences within this association range up to hundreds of meters in thickness, and thus a substantial oceanic sedimentation history is represented. The discordance-related uncertainties in the zircon ages also leave room for a substantial range in igneous ages (up to $50 \mathrm{~m}$.y.). Such a range may reflect a time and space interval between the sea floor spreading formation of juvenile crust, the subsequent growth of a seamount on such crust, or some form of offridge magmatism superimposed on juvenile crust. The broad age constraints outlined above lead to a late Paleozoic age assignment for this complex ocean floor assemblage.

Regional metamorphism in upper greenschist to primarily amphibolite facies conditions marks the disruption of the late Paleozoic ocean floor assemblage and its mixing into ophilitic melange. Time constraints on this important process can be derived from geological relations and $\mathrm{K} / \mathrm{Ar}$ data on amphibolite tectonite melange blocks. The $\mathrm{K} / \mathrm{Ar}$ ages are 
summarized in Figure 4. They cluster in the 180 to 200 m.y. range, although geological relations show that the amphibolites and their melange host pre-date the $200 \mathrm{~m}$.y. igneous age group. Textural overprints suggesting resetting of the $\mathrm{K} / \mathrm{Ar}$ systems are present only in samples located within contact aureoles that are superimposed over the melange. Aureoles of 200, 160 and about $110 \mathrm{~m} . y$. age are present along different segments of the ophiolite belt. In each case inner aureole amphibolite blocks have totally regenerated amphibole with $\mathrm{K} / \mathrm{Ar}$ ages that are similar to zircon ages on the cross-cutting intrusives. Amphibolites from locations outside obvious aureoles and with $\mathrm{K} / \mathrm{Ar}$ ages in the $180 \mathrm{~m}$.y. range show incipient textural and compositional changes in their amphibole grains. Overprinting features are almost lacking in samples which fall in the 190 to $200 \mathrm{~m}$.y. range, except along the Tuolumne segment where the only contact metamorphic event was at $200 \mathrm{~m} . \mathrm{y}$. It is unlikely that a regional resetting event would occur without leaving a textural imprint, and thus the 190 to $200 \mathrm{~m}$.y. ages are interpreted as a near minimum age constraint for the development of the amphibolites. This is similar to the Late Triassic metamorphic-deformation peak determined for oceanic and continental margin rocks juxtaposed along the Foothills suture [Sharp et al., 1982]. Thus regional metamorphism and ophiolitic melange development may be linked in time to the suturing of the late Paleozoic ocean floor assemblage to rocks of continental margin affinity.

\section{Tectonostratigraphic Framework of the OPHIOLITE BELT}

In previous sections the regional setting of the ophiolite belt was reviewed and a geochronological framework was established. In this section detailed structural-stratigraphic relations within the belt are discussed with an emphasis on how the igneous history of the belt relates to regional patterns in sedimentation and deformation. Detailed relations along four segments of the belt are summarized in a series of tectonostratigraphic columns (Figure 5). In contrast to conventional stratigraphic columns these columns are tectonostratigraphic in nature in that deformational and metamorphic episodes as well as igneous and sedimentary sequences are represented. The columns are diagrammatic reconstructions based on map-scale and detailed field relations with time constraints given by geochronological and biostratigraphic data. Zircon ages for the two younger ophiolitic age groups cluster near important period and epoch boundaries. Considering the discussions of Harland et al. [1964], Lambert [1971], and Armstrong [1978] ages of about $200 \mathrm{~m} . \mathrm{y}$. are considered Jura-Trias, and the boundary between Middle and Late Jurassic time is considered to be about $160 \mathrm{~m}$.y. Spatial variations along the ophiolite belt for these two critical slices in time are represented along horizontal rows in Figure 5.

Lower Mesozoic volcanic-sedimentary sequences show an overall consistency in lithologic character along the western Sierra region. However, rapid lateral variations over short distances due to both local facies changes and tectonic disruption inhibit detailed stratigraphic correlations. Nevertheless broad correlations can be based on regional continuity between similar rock associations with similar age constraints. A critical basis for establishing the correlations is the demonstration of basement continuity.

\section{Upper Paleozoic Ophiolitic Basement}

Upper Paleozoic ophiolitic rocks of the central and southern Sierra show a remarkable degree of consistency both in geological character and geochronological development. The association of rock types in the ophiolitic melange is constant along the entire $375 \mathrm{~km}$ length of the belt, and thus it appears that all segments of the belt were derived from a common protolith. Such basement continuity establishes at least broad tectonostratigraphic ties between Jura-Trias and later Jurassic rock assemblages that were either intruded into or deposited on top of the basement.

The geologic history of the upper Paleozoic basement prior to petrogenesis of the early Mesozoic ophiolites and volcanic-sedimentary sequences is of great importance in understanding the early development of the ophiolite belt. Upper Paleozoic ophiolite had been disrupted, metamorphosed and mixed into serpentinite melange in Triassic time. The remnants of a regional unconformity between the basement and Jura-Trias volcanic-sedimentary sequences are preserved along the Kaweah and Tuolumne segments of the belt. Detailed relations along the Kaweah segment are discussed in Saleeby [1979] and summarized in Figure 5. Here Jura-Trias pillow lava was erupted across a substrate consisting of ophiolitic sedimentary debris. The debris was locally derived and appears to have sat directly on its serpentinite melange source. Along the Tuolumne segment the Jura-Trias unconformity surface appears to have been an uplifted block of serpentinized peridotite that grades to the north and west into serpentinite-matrix melange. The remnants of this surface are preserved along the lower Tuolumne River (Figure 3) where non-deformed Penon Blanco pillow basalt lies directly on highly deformed ultramafic tectonite. A similar unconformity between ophiolitic melange and Jura-Trias strata of the central belt presumably extended northward into the Bear Mountains segment (Figures 1 and 2). However, Jurassic deformations have obliterated any remnants of such a surface.

The submarine landscape prior to deposition of the JuraTrias strata apparently consisted of fault bounded ridges of serpentinized peridotite, metamorphosed mafic rock, chert and carbonates, and serpentinite melange. Locally derived serpentinite debris flows and mafic, chert and carbonate talus breccias are the only remnants of a sedimentary record following the disruption and metamorphism of the basement and preceding the deposition of the Jura-Trias strata. Modern oceanic environments which display such a landscape include large oceanic fracture zones [Bonatti and Honnorez, 1976; Fox et al., 1976] and the inner walls of sediment-poor trenches [Evans and Hawkins, 1979; Hawkins et al., 1979]. On the basis of a wide range of regional geological considerations it was suggested that disruption and emplacement of the late Paleozoic ocean floor assemblage occurred by a combination of transform and convergent tectonics [Saleeby, 1980]. The importance of transform tectonics along the ancient California margin is suggested by tectonic truncations, regional patterns in aberrant paleomagnetic pole positions, and displaced faunal belts. Evidence for convergence is more direct, and includes early Mesozoic magmatic belts in eastern California and the apparent remnants of an early Mesozoic accretionary wedge. This wedge includes the ophiolitic melange basement rocks and upper Paleozoic to Triassic rocks of the central belt and Calaveras Complex. 
Ophiolitic basement rocks are intimately mixed with these chert-argillite melange belts as are remnants of accreted upper Paleozoic seamounts. Such seamount fragments occur in the central belt with a major ophiolitic melange exposure (Clark [1976]; W. H. Wright III and J. B. Saleeby, ongoing field studies) and are encased in upper Paleozoic to Triassic chert-argillite melange of the Calaveras Complex.

Late Paleozoic ocean floor assemblages form a major accretionary belt that stretches from the southern Sierra Nevada into northern British Columbia [Davis et al., 1978]. Important elements of such assemblages include upper $\mathrm{Pa}$ leozoic ophiolite and seamount fragments, Triassic metamorphic blocks and upper Paleozoic to lower Mesozoic chert-argillite assemblages. The geographic location of where the ocean floor formed is unknown, but paleobiogeographic evidence suggests that it was a substantial distance from the ancient continental margin. Upper Paleozoic limestone blocks that occur throughout this regional accretionary belt, and in melange belts of the western Sierra [Douglass, 1967; Saleeby, 1979] contain fossils that are thought to be diagnostic of an equatorial oceanic faunal belt [Danner, 1976, 1977; Nestel, 1980]. This faunal belt was for the most part out of communication with North American equatorial forms. The limestone blocks appear to have been derived from the seamount fragments, and in some locations the fossils are from carbonate buildups still attached to their volcanic substratum. Thus the accreted oceanic assemblages appear to be substantially out of place.

The upper Paleozoic oceanic assemblage of the western Sierra represents the accretionary nucleus for the growth of a complex association of Mesozoic igneous and sedimentary rocks of ensimatic character. Triassic-age regional metamorphism, melange development and suturing with continental margin rocks presumably marks accretion of the oceanic assemblage to the continent along a convergent plate juncture.

\section{Jura-Trias Volcanic and Sedimentary Sequences}

Volcanic and sedimentary sequences of Jura-Trias age which formed unconformably above ophiolitic melange basement are preserved along the Kaweah, Tuolumne and Bear Mountains segments of the belt. The tightest age constraints exist on rocks of the Tuolumne segment where the Penon Blanco volcanic sequence sits above ultramafic tectonites and serpentinite melange of the basement. The base of the Penon Blanco Formation consists of greater than $1000 \mathrm{~m}$ of aphyric pillow basalt. Above the basalt lies up to $30 \mathrm{~m}$ of radiolarian chert with numerous fine greenish tuffaceous intervals. Radiolaria from the chert interval are early Mesozoic in age (D. L. Jones, personal communication, 1979). The chert interval grades upward into fine crystal and lapilli tuff which is overlain by a thick sequence

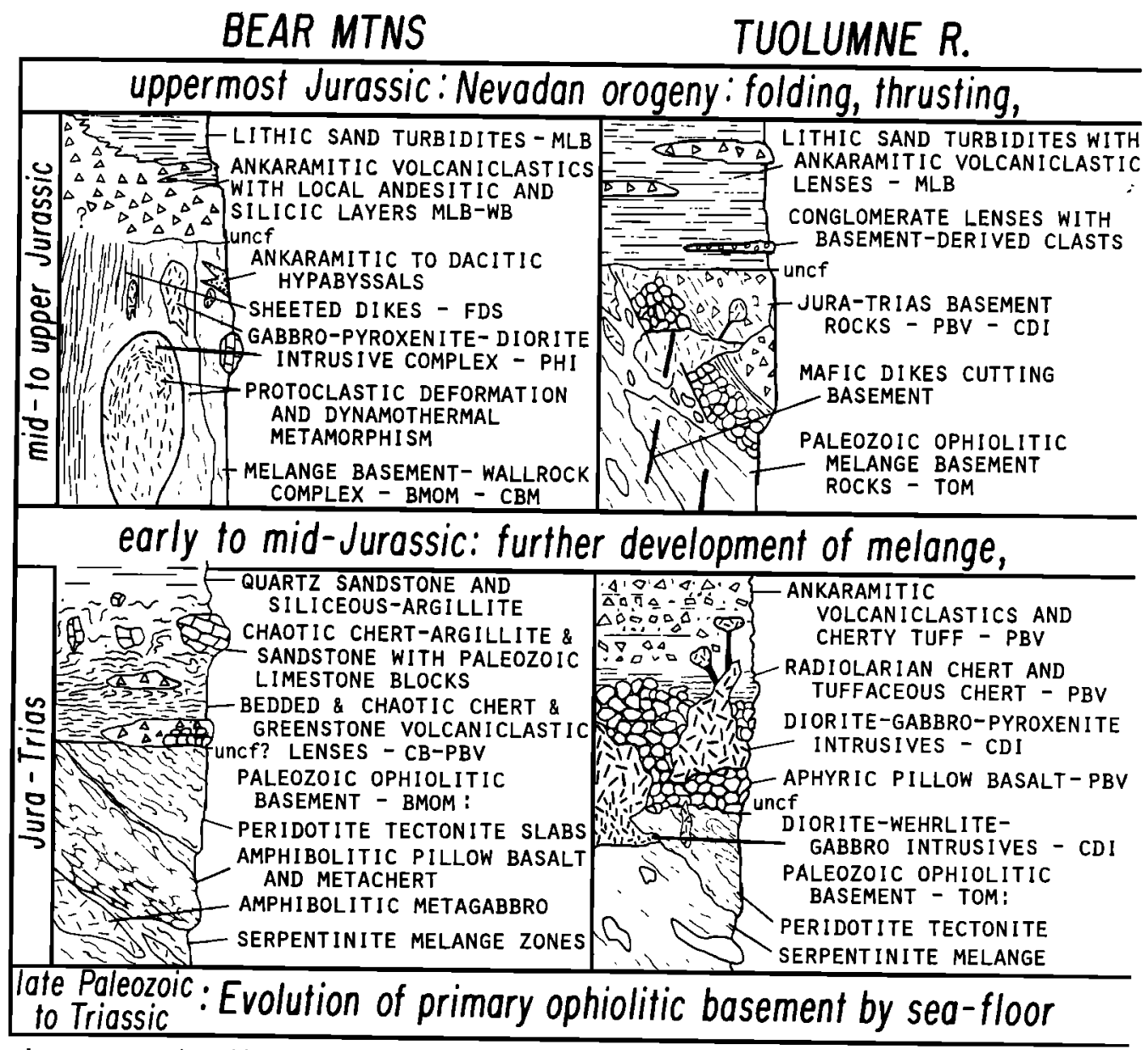

Fig. 5. Diagrammatic tectonostratigraphic columns for four key locations along the ophiolite belt. Note that preexisting basement for each time frame is shown by slightly lighter shades. 
of ankaramitic volcaniclastic rocks (coarse clinopyroxene phyric-olivine basalt). Subordinate plagioclase and/or hornblende phyric basaltic-andesite also occurs in the volcaniclastic sequence. This sequence is in excess of $2 \mathrm{~km}$ thick and consists of pyroclastic flow breccias, massive and bedded crystal and lapilli tuffs, and local pillows and broken pillow breccia.

Plutonic rocks that are genetically related to the ankaramite-rich volcaniclastic sequence consist of the Chinese Camp and Don Pedro intrusives (informal units used by Morgan [1976]). The genetic link was first suggested by $\mathbf{B}$. A. Morgan (1977, personal communication), based on similar clinopyroxene compositions in both plutonic and volcanic rocks. Field and petrographic investigations of this study strongly support Morgan's suggestion. The Chinese CampDon Pedro intrusives consist of a myriad of small injections which range from diorite to wehrlite in composition. Intense shattering, synplutonic veining by low-grade mineral assemblages and complex agmatites are all suggestive of a shallow subvolcanic origin. Some phases are coarsely clinopyroxene porphyritic, and very similar in appearance to the main clast population in the ankaramitic breccias. Furthermore, scattered clinopyroxene and hornblende megacrysts of identical character occur in both the intrusives and volcanics. Finally, cognate xenoliths of wehrlite, clinopyroxenite and diorite that are identical to some Chinese Camp-Don Pedro intrusive phases occur locally in Penon Blanco volcaniclastic beds. The volcano-plutonic association of the Penon Blanco Formation and the Chinese Camp-Don Pedro intrusives is interpreted as the remnants of a Jura-Trias volcanic center. As shown in Figure 3 the Chinese Camp-Don Pedro intrusives are concentrated in the lower pillow lava section of the volcanic sequence, but they also extend well up into the ankaramitic section. Some massive ankaramitic horizons may actually be sills that are linked to the intrusives. The eruptive history of the volcanic center began with capping of the basement by aphyric pillow lava not unlike ocean ridge basalt. Following a modest amount of radiolarian chert and fine tuff sedimentation, a thick ankaramitic volcaniclastic cone was constructed. Intrusive contacts between the subvolcanic intrusives and the basement are only locally preserved due to Jurassic deformations, but a widespread statictextured metamorphic overprint and reset $\mathrm{K} / \mathrm{Ar}$ systematics in amphibolite of the basement mark a broad thermal imprint related to the volcano-plutonic center. The remnants of a steep metamorphic gradient are also preserved in the Penon Blanco volcanic section. Here hornblende hornfels assemblages of the lower pillow section grade upward into statictextured greenschist and then progressively into very lowgrade greenschist assemblages in the upper volcaniclastic sequence. The total thickness of the Penon Blanco volcanic pile is unknown due to the unconformity with the overlying Mother Lode belt.

The Penon Blanco volcanics run northward from the

KAWEAH R.

KINGS R.

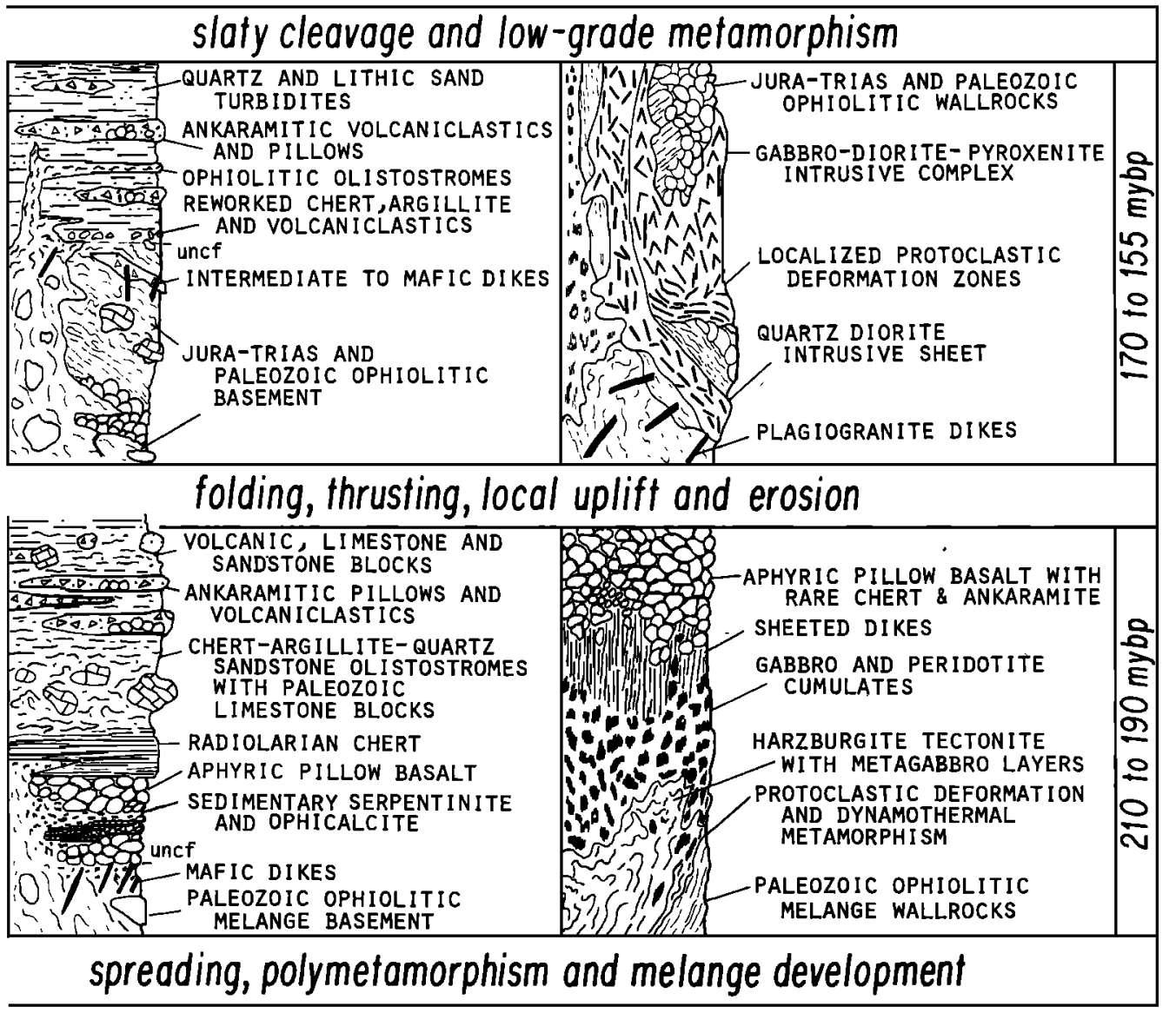

Fig. 5. (continued) 
Tuolumne region and appear to extend into the central belt melange (Figure 1). The structural and stratigraphic relationships are not clear along this part of the central belt due to the presence of infolds and fault slivers of mid- to Late Jurassic strata. Part of this complex area is shown as central belt melange and broken formation in Figure 2. Greenstone and lesser ankaramitic volcanic rocks which appear to be the northern extension of the Penon Blanco sequence are mixed with chert-argillite-sandstone melange along the southern part of the central belt. Upper Paleozoic limestone blocks also occur in the mixture [Douglas, 1967], and in some cases they are encased in pebble-cobble mudstone suggestive of a slide-block origin. Pebble to cobble-size clasts of chert, metabasalt and marble, and the remnants of sedimentary serpentinite beds mark local contributions to the central belt from the ophiolitic basement. Other important admixtures to the melange include bedded intervals and blocks of quartzrich sandstone and quartzite [Behrman, 1978a, b]. This diverse melange assemblage probably originated unconformably above the Bear Mountains ophiolitic basement or at least formed in a position where it could receive detritus from the basement. Unfortunately, remnants of any primary contacts between these assemblages are lacking as a result of Jurassic deformations. Such deformations include folding and thrusting episodes which both pre- and post-dated deposition of the younger volcaniclastic-slate units [Duffield and Sharp, 1975; Behrman, 1978a, b]. A similar structural chronology exists for similar central belt rocks of the Kaweah segment, however, some primary relations with the basement are preserved [Saleeby, 1979].

The highest structural-stratigraphic levels of the Kaweah melange consist of locally-derived serpentinite debris flows with fragments of metabasite, peridotite and chert. JuraTrias strata above and interbedded with the ophiolitic debris include abundant pillow lava and broken pillow breccia, chert, limestone, and ophicalcite (carbonate-cemented serpentinite breccia). Dikes and small irregular intrusive bodies of mafic to intermediate composition, which can locally be mapped directly into the pillowed rocks as their feeders, cut the underlying serpentinite melange as well as the lower intervals of the Jura-Trias section. Above the pillow-rich sequence lies a $200 \mathrm{~m}$ sequence of argillaceous and tuffaceous chert which grades into a chaotic sequence of olistostromes. The olistostromes consist of clasts and slabs of chert, upper Paleozoic limestone, quartz sandstone and ankaramite within a siliceous argillite and chert-pebble mudstone matrix. The thickness of the olistostrome sequence is unknown due to an unconformity with the overlying Jurassic volcaniclastic-slate unit. However, it must have measured on the order of thousands of meters inasmuch as some limestone blocks range up to $500 \mathrm{~m}$ in diameter and a $400 \mathrm{~m}$ thick ankaramitic volcanic sequence lies within it.

Jura-Trias strata of the Kaweah River area consists of a combination of elements present in the Jura-Trias assemblages exposed along the Tuolumne and Bear Mountains segment of the belt (Figure 5). Basaltic volcanism along the Tuolumne segment spread across a basement exposure that was apparently swept clean of ophiolitic debris. In the Kaweah region the pillow lavas were deposited above and interbedded with such debris. Both the Kaweah and Bear Mountains assemblages contain a basinal assemblage dominated by chert, argillite and olistostromal units. Externally derived admixtures to the basinal assemblages include upper
Paleozoic limestone blocks and quartz-rich clastic rocks. Both have nearby sources in the seamount remnants of the oceanic basement complex, and in continental margin rocks exposed east of the Foothills suture. Blocks of ankaramitic volcanic rock possess a local source within the Kaweah section. Such blocks may also have been derived from a major volcanic constructional center such as the Penon Blanco section.

The Paleogeographic setting envisioned for Jura-Trias time is a complex basinal framework with submarine ridges or fault scarps exposing ophiolitic melange basement rocks and the deformed remnants of upper Paleozoic seamounts. More distant exposures of continental margin rocks lie to the east. Within this framework chert and argillite sedimentation predominated except where ankaramitic volcanic constructional piles were built. Abundant slide blocks derived from such constructional centers, and from basement exposures, and the resulting chaotic mixtures with chert, mud and sand are considered a reflection of the tectonic instability of the basinal environment. Important insights into the evolution of the basin complex are derived from relationships exposed in the Kings River ophiolite.

\section{Kings River Ophiolite: Implications for Jura-Trias Basin}

The Kings River ophiolite represents the only complete and reasonably intact ophiolite sequence recognized in the Sierra Nevada. The ophiolite's tectonite-cumulate-sheeted dike-pillow sequence is represented in Figure 5. As discussed in Saleeby [1978], the apparent stratigraphic thicknesses are in reasonable agreement with the idealized ophiolite model [Coleman, 1977], although the top of a relatively thick pillow section is not exposed. The important aspect of a complete ophiolite sequence stressed here is that it presumably represents the products of sea-floor spreading [Dewey and Bird, 1971; Coleman, 1977].

The focus of this discussion is the question of where did sea-floor spreading generation of the Kings River section occur relative to the rest of the ophiolite belt. This is addressed by considering the subtle yet significant complexities in the relations between the ophiolite section and the adjacent Kaweah melange. Rocks of the Kaweah melange bound the western margin of the ophiolite and extend into the basal ultramafic tectonites as narrow screen-like bodies. The entire melange assemblage in this area has been penetratively metamorphosed at amphibolite grade. The result of this metamorphism has been the transformation of mafic, chert and limestone blocks into amphibolite, metaquartzite and marble layers which lie concordantly within an ultramafic schist host. The one plagiogranite block located in this area was transformed into the quartz-plagioclase-garnet gneiss layer of sample KSM10. The original metamorphic mineralogy of the ultramafic host is difficult to resolve due to widespread static-textured talc growth related to Cretaceous contact metamorphism. However, nematoblastic antigorite and tremolite appear to have been important phases and local vestiges of anthophyllite are present. The metamorphic tectonite fabrics of the ultramfic schist and its inclusions map out in continuity with the pervasive mylonitic fabric present in the lower levels of the Kings River ophiolite. This is shown diagramatically in Figure 5, and is clear in maps and structure diagrams in Saleeby [1978]. Furthermore, the mylonitic fabric of the lower Kings River section is manifest by intense protoclastic deformation in the lower igneous 
sequence, shown by countradictory intrusive and deformational relations between gabbroic masses within peridotite, and rare dioritic and felsic segregations within gabbroic masses.

The relations outlined above indicate that the Kings River ophiolite underwent its $200 \mathrm{~m}$.y. igneous petrogenesis in close proximity to the pre-existing Kaweah melange, and that the melange exhibits a dynamothermal contact aureole presumably related to the primary heat of the Kings River section. The metamorphosed melange remnants may represent a wallrock border facies that was intruded by hot subsolidus peridotite and protoclastically deforming gabbroic magma. Such intrusive relations may mark a fossil margin of the rift basin which gave rise to the Kings River ophiolite section, or occur where screens of wallrock were stranded within such a rift basin. Alternatively, the Kings River section may have been tectonically transported into its contact relations with the Kaweah melange while it was still hot enough to have patches of gabbroic magma remaining along its lower stratigraphic levels. In either case, general or direct proximity is required between the site of genesis for the Kings River ophiolite and the older Kaweah melange.

Such a spatial relation between the sea-floor spreading genesis site of the Kings River section and the significantly older melange complex is not likely to form at a mid-ocean ridge. Furthermore, during the Jura-Trias formation of the Kings River section, the adjacent melange was basement for the basinal volcanic-sedimentary sequences. The interpretation favored here is that the basinal conditions that were superimposed over the melange basement are a result of rifting. Jura-Trias pillow sections erupted directly across the basement may be manifestations of the rifting, but the extreme product was the generation of juvenile oceanic crust represented by the Kings River section. Original spatial relations between the Kings River section and the Jura-Trias basinal strata are unknown due to Jurassic deformations, uplift and erosion. It is possible that the basinal strata sat above the Kings River pillow section, but were removed tectonically or by erosion. Such a relation may also account for the local occurrence of ankaramite in the upper levels of the Kings River pillow section. The important point here is the primary link between the ophiolite section and the basinal strata based on the age data and basement relations. The most remarkable aspect of geologic history in the western Sierra region is that the process outlined above repeated itself in mid- to Late Jurassic time.

\section{Mid- to Upper Jurassic Basinal Strata}

The most complete and intact history of basinal sedimentation in the western Sierra Nevada lies in the mid- to Upper Jurassic volcaniclastic-slate sequences. The gross pattern of intercalated volcanic and sandstone-mudstone units is depicted in Figure 1, but interstratification occurs down to very small scales involving individual sedimentation units. The Mother Lode and Western belts are very similar, and appear to be complimentary limbs of major anticlinal structures. The only notable difference in the two belts is the occurence of local dacitic volcanic dome-like assemblages in the Western belt [Clark, 1964; Behrman, 1978b; Behrman and Parkison, 1978] and a lack of such in the Mother Lode belt. However, inspection of Figure 1 shows a much larger sampling available for rocks of the western belt, and thus the lack of local silicic analogues in the Mother Lode belt is not considered significant. This discussion will focus primarily on the Mother Lode belt inasmuch as there is greater stratigraphic control and more petrographic data for this belt, and in general it is less deformed than the western belt.

The remnants of a regional unconformity between the volcaniclastic-slate sequences and older Jura-Trias and upper Paleozoic assemblages exist along the base of the Mother Lode belt. This belt is roughly an east-dipping homoclinal sequence with its basement exposed along the TuolumneBear Mountains segment of the ophiolite belt. In the Tuolumne area Penon Blanco volcanics and the Chinese Camp intrusives are in contact with slaty flysch of the Mother Lode belt (Figure 3). Northward along the contact from the Tuolumne River area Penon Blanco ankaramite is cut out of the section by pre-Late Jurassic faults which disrupt the Jura-Trias assemblage into a narrow melange unit. These faults place Chinese Camp intrusives to a higher structural level so that slaty mudstone of the Mother Lode belt lies immediately on diorite. Further north Penon Blanco volcanics and related intrusives emerge from a cover of superjacent strata in essentially the same stratigraphic position. The contact at the base of the Mother Lode belt was originally mapped by Morgan [1976] as a thrust fault. Further investigation has revealed that it is a faulted unconformity. In areas of critical exposure well-preserved bedding in the slaty mudstone is parallel to the contact and only locally sheared. Shearing is absent in the underlying igneous rocks, and a hummocky altered horizon may be the remnants of a paleoweathered zone. Locally derived clasts of greenstone, ankaramite and diorite occur as rare admixtures in the overlying mudstone. A large cobble-size diorite clast, which is petrographically similar to Chinese Camp diorite, yielded a $198 \mathrm{~m} . y$. zircon age (sample MLB1). This age is the same as ages determined on the Chinese Camp-Don Pedro intrusive complex (Table 1, Figure 4), and together with the petrographic similarities substantiates the existence of Chinese Camp-Don Pedro type intrusives in the Mother Lode basement regime. The diorite clast was situated within a channel conglomerate bed with scattered greenstone clasts and abundant chert, argillite and metaquartzite clasts. The source for the channel conglomerate appears to have been a terrane with both basinal volcanic-sedimentary and continental margin-type assemblages. First cycle and reworked material from a central belt-type assemblage would produce such a mixture.

The Mother Lode belt in the Tuolumne area is well over $1000 \mathrm{~m}$ thick, but the top of the section is not exposed. It consists primarily of thin bedded turbidites with a mixed provenance of first cycle volcaniclastic material and uplifted central belt-type assemblages [Clark, 1964; Behrman and Parkison, 1978]. Basin plain, slope and channel facies of a classic submarine fan complex are all present within the slaty strata. Such strata are Oxfordian to Kimmeridgian in age, as indicated by bivalve and ammonite faunal assemblages [Clark, 1964]. Northward from the Stanislaus River area the slaty strata interfinger with volcanic units that range up to $1000 \mathrm{~m}$ in thickness. The volcanic units are predominantly ankaramitic in composition and consist of pillow lava, pillow breccia, crystal and lapilli tuff and tuff-breccia. The lowermost volcanic unit reaches its maximum thickness in the Cosumnes River area (Figure 2), where it is Callovian in age.

A depositional contact was originally mapped between 
Mother Lode belt rocks and rocks of the central belt [Clark, 1964]. Later studies considered this contact to be tectonic in origin primarily on the basis of the older assemblage being a melange [Duffield and Sharp, 1975]. This critical relationship was reinterpreted by Behrman [1978b] as a faulted unconformity which is consistent with the relations present along the Tuolumne segment. The unconformable relations in the Cosumnes River area are supported by the presence of central belt and ophiolitic detritus in Mother Lode clastic units [Behrman, 1978b; Behrman and Parkison, 1978], and the presence of ankaramitic to dacitic hypabyssal rocks which cross-cut rocks of the melange. Such hypabyssal rocks are presumably related to the ankaramitic to dacitic volcanic units present in strata of the Mother Lode and western belts. Infolds and fault slivers of Mother Lode-type rocks that occur in the central belt melange and broken formation (Figure 2) may represent stratified remnants above the transposed unconformity. Such a relationship is well-preserved along the Kaweah segment of the belt.

Mid- to Upper Jurassic strata exposed along the Kaweah segment of the ophiolite belt consist of slaty flysch with ankaramitic and andesitic volcaniclastic interbeds. These strata are preserved as tightly folded erosional remnants which lie unconformably above ophiolitic and chert-argillite melange [Saleeby, 1979]. Abundant chert, argillite, quartz sandstone and lesser greenstone detritus constitute an important Jura-Trias detrital component, and sedimentary serpentinite and ophiolitic olistostrome beds represent debris derived from the ophiolitic basement. The ophiolitic material was derived from serpentinite diapiric protrusions which carried blocks of other ophiolitic lithotypes. Local intermediate-composition hypabyssal rocks, which are presumably related to the volcanic intervals, cut the ophiolitic melange basement and the Jura-Trias strata. The contact between the Kaweah volcaniclastic-slate sequence and the older assemblages is highly interdigitated parallel to the slaty cleavage direction and to axial surfaces of folds in the flysch beds [Saleeby, 1979]. Such structural relations are similar to those present in the central belt melange and broken formation unit to the north. In the Kaweah region this relation is shown to be a transposed unconformity by the direct connection of sedimentary serpentinite beds with basement source rocks by the remnants of protrusion dikes.

Stratigraphic relations in mid- to Upper Jurassic basinal sequences deposited above the Sierran ophiolite belt are summarized in Figure 5. A similar paleogeographic setting to that of the Jura-Trias basin is envisaged, although in later Jurassic time exposures of Jura-Trias assemblages added to the sediment flux supplied by active volcanic centers, and continental margin and oceanic basement rocks. The flysch sequences which gave rise to the slate units are the remnants of coalescing submarine fans which experienced interruptions in depositional style due to the growth of predominantly ankaramitic volcanic centers within the basinal setting [Behrman and Parkison, 1978; Saleeby et al., 1978]. The main difference between the mid- to Late Jurassic and the Jura-Trias basin was a greater influx of externally derived sediment in the younger basin. In the Jura-Trias basinal sequences hemipelagic strata are in greater abundance over clastic strata of possible submarine fan origin, whereas in the younger sequences submarine fan strata greatly predominate. This perhaps reflects a component of maturing in the continental margin environment during the time that elapsed between the two basinal environments. As with the JuraTrias basin, the mid- to Late Jurassic basin can be linked to rifting and ophiolite formational processes.

\section{Mid- to Upper Jurassic Ophiolitic and Plutonic Rocks}

Evidence of rifting and related ophiolite formation during mid- to Late Jurassic time is widespread in the western Sierra Nevada, and throughout much of California. The remnants of a rift margin are exposed along the Bear Mountains segment of the belt where the Folsom dike swarm intrudes the Bear Mountains ophiolitic melange. The predominance of sheeting structure in the dike swarm indicates a tremendous component of extension during dike emplacement. The occurrence of similar age mafic dikes in great abundance in chert-argillite melange and continental margin rocks exposed east of the Melones fault [Sharp, 1980], and locally within opholitic melange and the Jura-Trias sequences of the Tuolumne and Feather River segments of the ophiolite belt, indicate that mid- to Late Jurassic extensional tectonics was widespread throughout the western Sierra region. Furthermore, the extension of ankaramitic volcaniclastic strata of the western Jurassic belt into the upper stratigraphic levels of the Smartville ophiolite ties the production of juvenile crust to the proximity of the pre-existing ophiolite basement and its overlying basinal sequences. Thus the mid- to Late Jurassic basinal environment can be directly related to rifting and ophiolite formation as can the Jura-Trias basin.

Unlike the remnants of the Jura-Trias rifting episode, midto Late Jurassic ophiolitic assemblages covered by basinal strata are widespread in other regions of California which include the western Klamath Mountains and Coast Ranges [Saleeby et al., 1979; Blake and Jones, 1980; Harper, 1980; Hopson et al., 1980]. It has been suggested that the Klamath and Coast Range exposures are the main vestiges of juvenile crust created by the mid- to Late Jurassic rifting event recorded in the western Sierra [Saleeby, 1980]. It follows that significant quantities of the Late Paleozoic and JuraTrias assemblages may have been removed from the evolving continental margin during rifting and basin opening. This is in concert with the observation that definitive information and critical relations are sparce and fragmental for the older assemblages.

The Pine Hill intrusive complex poses an important question concerning the rift-edge exposed along the Bear Mountains belt. The intrusive complex could be interpreted as the deformed cumulate sequence of a typical ophiolite section. Of course this cannot be the case due to its intrusive relations with the Bear Mountains melange. Furthermore, the dioritic end members of the Pine Hill complex contain minor but significant amounts of igneous biotite which is unlike typical ophiolitic cumulate sequences [Coleman, 1977]. The early abundance of diopsidic-augite in the Pine Hill intrusion along with subordinate olivine in ultramafic and gabbroic compositions makes the intrusion a suitable plutonic analogue to the ankaramitic volcanic units of the Mother Lode and western belts. Clinopyroxenite xenoliths similar to phases of the Pine Hill complex occur in the lowermost Mother Lode belt volcanic unit. Furthermore, the Callovian faunal age for this volcanic unit is essentially the same as the 163 m.y. zircon age for the Pine Hill complex 
[Armstrong, 1978], and in addition, ankaramitic units in both the Mother Lode and western belts increase in thickness as the Pine Hill region is approached.

It is suggested that the Pine Hill complex and the ankaramitic hypabyssal rocks of the central belt are the subvolcanic roots of a major ankaramitic volcanic constructional center. The close spatial and temporal association of the Pine Hill complex and the Folsom dike swarm is consistent with the extension of western belt ankaramitic volcaniclastic strata into the Smartville ophiolite volcanic section. It follows that a major volcanic constructional center was probably built over the edge of the mid- to Late Jurassic rift basin.

Mid- to Late Jurassic age intrusive complexes characterized by clinopyroxene-rich ultramafic phases and biotitebearing pyroxene diorite occur in a number of locations along the western Sierra Navada-Klamath Mountains region [Snoke et al., 1982]. The Sierran locations are shown in Figure 1. The Pine Hill complex resembles such a plutonic association, although unlike Pine Hill, many of the complexes also contain late-stage granitoid bodies. Such an association occurs in the lower Kings River area where a 170 m.y. clinopyroxenitic to dioritic pluton cuts the ophiolite, but is in turn cut by a $157 \mathrm{~m} . y$. quartz dioritic intrusive sheet (Figures 4 and 5). It has been suggested that the peridotitic to dioritic intrusive complexes represent the plutonic remnants of island arc volcanic centers with overall calc-alkaline trends, but with a peculiar tendency to also erupt ankaramitic lavas [Snoke et al., 1982]. Such considerations lead to the question of a modern plate tectonic analogue for the production of ankaramite-rich volcanic sequences in concert with the formation of polygenetic ophiolitic assemblages.

\section{Polygenetic Ophiolite and Plate Tectonics}

The Sierra Nevada ophiolite belt and related basinal volcanic-sedimentary sequences exhibit a repetition in tectonic processes over a wide time span with a remarkable degree of consistency. At both 200 m.y. and 160 m.y. a preexisting ophiolitic basement complex was rifted apart with the formation of juvenile ophiolitic crust, while the basement was covered with basinal volcanic-sedimentary sequences. Both basinal sequences were characterized by the eruption of ankaramitic volcaniclastic rocks. Furthermore, both systems included complex basement uplifts which added locally-derived detritus and large slide masses to the basinal strata. The 200 m.y. basin framework was disrupted during a compressional phase of orogeny prior to the development of the 160 m.y. framework and possibly prior to the end of early Jurassic time. Within 10 to 15 m.y. after the formation of the younger basin another compressional orogenic phase disrupted that framework. This phase is recognized as the classical Nevadan orogeny [Hinds, 1934]. Thus neither basin system persisted as a stable tectonic entity for a significant time span following rifting and formational stages.

The closest modern analogue that can be recognized for such a complex tectonic and petrogenetic history is the Solomon Islands system. This complex arc system consists of non-volcanic islands or remnant arc fragments exposing upper Cenozoic volcanic-sedimentary sequences and metamorphosed mafic and ultramafic basement rocks [Coleman, 1970; Hackman, 1973]. Volcanic islands of the New Georgia Group sit in a frontal arc position and are characterized by ankaramitic and picritic constructional centers [Stanton and
Bell, 1969; Carmichael et al., 1974]. Separating the frontal and remnant arc segments is a partially closed inter-arc basin system floored by oceanic-type crust [Karig, 1972]. Major transcurrent fault zones have disrupted the non-volcanic remnant arc into en echlon ridges and basins, and deep fractures and fault zones occur along the frontal arc region. Such deep fractures may be related to the tapping of picritic and ankaramitic lava sources [Snoke et al., 1982].

It is suggested that a complex fractured and rifted ensimatic arc environment such as the Solomon Islands is the type of tectonic setting where multiple ophiolite formation episodes may occur in association with the growth of ankaramitic volcanic centers and the formation of complex sedimentary basins. Such an arc system presumably begins its evolution within a primary oceanic or ophiolitic basement regime. The upper Paleozoic oceanic assemblages of the western Sierra represent such a primary basement regime. The disruption of this assemblage into a regional melangetectonite belt presumably records the establishment of a plate juncture system that would lead to the growth of primitive volcanic arc construction centers and the opening of inter-arc basins. Disruption of the 200 and 160 m.y. basin systems shortly following their formation points to an iniherent instability in such basins. However, the repetition of nearly identical petrotectonic assemblages in the 200 and 160 m.y. basin systems suggests that basinal framework destruction can be an intra-orogenic process without the complete reorganization of the plate juncture system.

Important questions arise concerning basinal framework destruction from structural relations preserved along both the 200 and 160 m.y. rift margins. In both the Kings River ophiolite and Folsom dike swarm-Pine Hill complex intense protoclastic deformation of juvenile material accompanied dynamothermal metamorphism of the adjacent wallrock complex. Such deformation regimes may mark major transform segments along the rift margins. Evidence suggesting Jurassic transform motions along the California continental margin regime is reviewed by Saleeby [1980]. Alternatively, these distinct deformational regimes may indicate that the edges of normal rifts begin to undergo compressional deformations almost immediately following the onset of rifting. Such a setting would be ideal for the obduction of young ophiolite sheets. Perhaps the eastern and northern margins of the Smartville ophiolite were thrust eastward oyer its bounding metamorphic wall in response to such a deformational regime. The point stressed here is that the basin edges underwent compressional-type deformations at essentially the same time that the basin was growing, and shortly thereafter the basin framework was disrupted by orogenic pulses. Such an inherent instability may be a common feature in small oceanic-type plates generated along complex continental margin environments.

\section{Conclusions}

Igneous assemblages that comprise the Sierra Nevada ophiolite belt are polygenetic in origin. The amount of time elasped between the 300,200 and $160 \mathrm{~m}$.y. igneous formation stages is significant. Complex sedimentation, deformation, metamorphism and erosional processes modified the evolying ophiolite belt between each igneous stage. It is clear that the Sierra Nevada ophiolite belt does not represent a fragment of open ocean crust and upper mantle. Perhaps the 300 
m.y. assemblage represents the vestiges of such an ideal ophiolite, but any clear evidence of such an origin has been obscured.

The Sierra Nevada ophiolite belt represents an ensimatic basement complex. Just as continental basement complexes develop through an overprint history of the igneous, sedimentary and metamorphic processes of the ensialic domain, the Sierran ophiolitic basement has developed through the overprinting of petrogenetic processes belonging to the ensimatic domain. Oceanic domains best suited for the longterm development of a polygenetic basement complex include island-arc-marginal basin systems. Initiation of such systems requires the existence of a primary basement to serve as an accretionary nucleus.

The upper Paleozoic ophiolitic and seamount-assemblages are remnants of the accretionary nucleus for the polygenetic basement complex. Tectonic accretion of the upper Paleozoic sea-floor assemblage probably occurred along transform and/or sediment-poor trench environments. The overprinting of primitive island arc-marginal basin processes over older trench or fracture zone processes is a recognized phenomenon in modern tectonic environments [Hilde et al., 1977; Curry et al., 1979; Hamilton, 1979]. Such a history is evident in the Sierran ophiolite belt where repeated rifting events produced 200 and $160 \mathrm{~m}$.y. ophiolitic assemblages within the confines of the accreted upper Paleozoic sea floor assemblage. The two rifting events possessed the ability to remove much of the original upper Paleozoic assemblage from the region of present-day exposure. Significant volumes of Jura-Trias and possibly later Jurassic material may also have been removed by rifting, and thus any attempts to make detailed paleotectonic reconstructions for Jurassic or pre-Jurassic time are poorly constrained.

The multiple rifting events and the ensuing basinal sedimentation patterns of the Sierran ophiolite belt record the production of a marginal or inter-arc basin system in the proximity of primitive volcanic arc and continental source regions. Such a pattern in ophiolite genesis is in contrast to the modern view that ophiolites represent open ocean crust and mantle that were obducted onto continental margins. Furthermore, the concept of ophiolite obduction is not applicable for the Sierran belt as a whole. In contrast the Sierran belt represents a polygenetic basement complex which reached its current crustal properties by igneous accretion in series with compressional deformations. Not only were two ophiolitic igneous suites generated within a pre-existing ophiolitic basement framework, but Jurassic arc-affinity rocks and Cretaceous batholithic rocks emplaced into the belt record further crustal growth without the involvement of underlying continental basement [Saleeby, 1980; Saleeby and Sharp, 1980]. It is not implied that the modern views of ophiolite genesis and emplacement are incorrect, but that in the case of the Sierran belt a more complex history exists. Furthermore, the complex history outlined above for the Sierran ophiolite belt is not without possible modern plate tectonic analogues in rifted and fractured arc-basin systems such as the Solomons arc system.

Acknowledgments. Field excursions, conversations and written communications with P. E. Behrman, B. A. Morgan, W. D. Sharp, R. K. Springer, W. H. Wright III, E. M. Moores and R. A. Schweickert were of great importance for this study. Patience and expertise in hand purification and sorting of zircon fractions by Cherilyn SunRidge-Saleeby were essential for this study. Critical reviews of the manuscript by R. G. Coleman, J. M. Mattinson and G. E. Gehrels were helpful. Support from NSF grants EAR7708691 and EAR 7925998 is gratefully acknowledged. Contribution 3583 of the Division of Geological and Planetary Sciences, California Institute of Technology.

\section{REFERENCES}

Armstrong, R. L., The pre-Cenozoic Phanerozoic time scale-A computer file of critical dates and consequences of new and inprogress decay constant revisions, Am. Assoc. Pet. Geol. Stud. Geol., 6, 73-91, 1978.

Bateman, P. C., and L. D. Clark, Stratigraphic and structural setting of Sierra Nevada Batholith, California, Pac. Geol. 8, 79-89, 1974.

Behrman, P. G., Pre Callovian rocks west of the Melones Fault Zone, central Sierra Nevada foothills, in Mesozoic Paleogeography of the Western United States, Paleogeogr. Symp. 2, edited by D. E. Howell and K. A. McDougall, pp. 337-348, Society of Economic Paleotologists and Mineralogists, Pacific Section, Los Angeles, Calif., 1978a.

Behrman, P. G., Paleogeography and structural evolution of a middle Mesozoic volcanic arc-continental margin; Sierra Nevada foothills California, Ph.D. dissertation, 301 pp., Univ. of Calif., Berkeley, $1978 b$.

Behrman, P. G., and G. A. Parkison, Paleogeographic significance of Callovian to Kimmeridgean strata-Central Sierra Nevada foothills, California, in Mesozoic Paleogeography of the Western United States, Paleogeogr. Symp. 2, edited by D. E. Howell and K. A. McDougall, pp. 349-360, Society of Economic Paleontologists and Mineralogists, Pacific Section, 'Los Angeles, Calif., 1978.

Bonatti, E., and J. Honnorez, Sections through the earth's crust in the equatorial Atlantic, J. Geophys. Res., 81, 4104-4116, 1976.

Carmichael, I. S. E., F. J. Turner, and J. Verhoogen, Igneous Petrology, McGraw-Hill, New York, 1974.

Chen, J. H., and J. G. Moore, Uranium-lead isotopic ages from the Sierra Nevada Batholith, J. Geophys. Res., in press, 1982.

Clark, L. D., Foothills fault system, western Sierra Nevada, California, Geol. Soc. Am. Bull., 7l, 483-496, 1960.

Clark, L. D., Stratigraphy and structure of part of the western Sierra Nevada metamorphic belt, California, U.S. Geol. Surv. Prof. Pap., 410, 70 pp., 1964.

Clark, L. D., Stratigraphy of the north half of the western Sierra Nevada metamorphic belt, California, U.S. Geol. Surv. Prof. Pap., 923, 26 pp., 1976.

Coleman, P. J., Geology of the Solomon and New Hebrides Islands, as part of the Melanesian re-entrant, Southwest Pacific, Pac. Sci., 24, 289-314, 1970.

Coleman, R. G., Ophiolites, Ancient Oceanic Lithosphere? Springer-Verlang, New York, 1977

Curray, J. R., D. G. Moore, L. A. Lawver, R. W. Raitt, and M. Henry, Tectonics of the Andaman Sea and Burma, Am. Assoc. Pet. Geol. Mem., 29, 189-198, 1979.

Danner, W. R., The Tethyan realm and the Paleozoic Tethyan province of western North America (abstract), Geol. Soc. Am. Abstracts, Programs, 8, 827, 1976.

Danner, W. R., Paleozoic rocks of northwest Washington and adjacent parts of British Columbia, in Paleozoic Paleogeography of the Western United States, Paleogeogr. Symp. 1, edited by J. H. Stewart, C. H. Stevens, and A. E. Fritsche, pp. 481-502, Society of Economic Paleontologists and Mineralogists, Pacific Section, Los Angeles, Calif., 1977.

Davis, G. A., S. R. Hart, and G. R. Tilton, Some effects of contact metamorphism on zircon ages, Earth Planet. Sci. Lett., 5, 27-34, 1968.

Davis, G. A., J. W. H. Monger, and B. C., Burchfiel, Mesozoic construction of the Cordilleran 'collage,' central British Columbia to central California, in Mesozoic Paleogeography of the Western United States, Paleogeogr. Symp. 2, edited by D. E. Howell and K. A. McDougall, pp. 1-32, Society of Economic Paleontologists and Mineralogists, Pacific Section, Los Angeles, Calif., 1978.

Dewey, J. F., and J. M. Bird, Origin and emplacement of the ophiolite suite: Appalachian ophiolites in Newfoundland, $J$. Geophys. Res., 76, 3179-3206, 1971.

Douglass, R. C., Permian Tethyan fusulinids from California, U.S. Geol. Surv. Prof. Pap., 583-A, 7-43, 1967.

Duffield, W. A., and R. V. Sharp, Geology of the Sierra foothills 
melange and adjacent areas, Amador County, California, U.S. Geol. Surv. Prof. F Fap., 827,30 pp., 1975.

Evans, C., and J. Hawkins, Mariana arc-trench system: Petrology of 'seamounts' on the trench-slope break (abstract), Eos Trans. $A G U, 46,968,1979$.

Fox, P. J., E. Schreiber, H. Rowlett, and C. McCamy, The geology of the oceanographer fracture zone: A model for fracture zones, J. Geophys. Res., 81, 4117-4128, 1976.

Hackman, B. D., The Solomon Islands fractured arc; in The Western Pacific, Island Arcs, Marginal Basins, Geochemistry, edited by P. J. Coleman, pp 179-191, University of Australia Press, Canberra, 1973.

Hamilton, W., Tectonics of the Indonesian region, U.S. Geol. Surv. Prof. Pap., 1078, 345 pp., 1979.

Harland, W. B., A. G. Smith, and B. Wilcock (Eds.), The Phanerozoic timescale, Geol. Soc. London Q. J., 120, 458 pp., 1964.

Harper, G. D., The Josephine ophiolite-Remains of a Late Jurassic marginal basin in northwestern California, Geology, 8, 333-337, 1980.

Hawkins, J. W., Jr., S. Bloomer, C. Evans, and J. Melchoir, Mariana arc-trench system: Petrology of the inner trench wall (abstract), Eos Trans. $A G U, 46,968,1979$.

Hilde, T. W. C., S. Uyeda, and L. Kroenke, Evolution of the western Pacific and its margin, Tectonophysics, 28, 148-165, 1977.

-Hinds, N. E. A., The Jurassic age of the last granitoid intrusives in the Klamath Mountains and Sierra Nevada, California, Am. J. Sci., 227, 182-192, 1934

Hopson, C. A., J. M. Mattinson, and E. A. Pessagno, Jr., Coast Range ophiolite, western California, in The Geotectonic Development of California, Rubey Volume I, edited by W. E. Ernst, pp. 419-510, Prentice-Hall, Englewood Cliffs, N. J., 1980.

Irwin, W. P., D. L. Jones, and T. A. Kaplan, Radiolarian from preNevadan rocks of the Klamath Mountains, California and Oregon, in Mesozoic Paleogeography of the Western United States, Paleogeogr. Symp. 2, edited by D. E. Howell and K. A. McDougall, pp. 303-310, Society of Economic Paleotologists and Mineralogists, Pacific Section, Los Angeles, Calif., 1978.

Karig, D. E., Remnant arcs, Geol. Soc. Am. Bull., 83, 1057-1068, 1972.

Krogh, T. E., A low contamination method for hydrothermal decomposition of zircon and extraction of $\mathrm{U}$ and $\mathrm{Pb}$ for isotopic age determinations, Geochim. Cosmochim. Acta, 37, 485-494, 1973.

Lambert, R. St. J., The pre-Pleistocene time-scale-A review, in The Panerozoic Time-Scale-A Supplement, Spec. Publ. 5, edited by W. P. Harland and E. H. Francis, pp.' 9-34, Geological Society of London, London, 1971.

Mattinson, J. M., Early Paleozoic ophiolite complexes of Newfoundland: Isotopic ages of zircons, Geology, 3, 181-183, 1975.

Mattinson, J. M., Ages of zircons from the Bay of Islands ophiolite complex, Western Newfoundland, Geology, 4, 393-394, 1976.

Menzies, M. A., E. M. Moores, K. Buer, D. Day, and W. Kemp, The Smartville ophiolite, Sierra Nevada foothills, California: Field trip guide, 23 pp., Int. Conf. on the Nature of Oceanic Crust, La Jolla, Calif., 1975.

Moores, E. M., Ultramafics and orogeny, with models of the U.S. Cordillera and the Tethys, Nature, 228, 837-842, 1970.

Moores, E. M., and M. Menzies, The Smartville terrane, northwestern Sierra Nevada, major pre-Late Jurassic ophiolite complex, Geol. Soc. Am. Abstracts Programs, 7, 352, 1975.

Morgan, B. A., Geology of Chinese camp and Moccasin quadrangles, Tuolumne County, California, Misc. Field Studies Map MF840, scale 1:24,000, U.S. Geol. Surv., Reston, Va., 1976.

Nestel, M. K., Permian Fusulinacean provinces in the Pacific northwest are tectonic juxtapositions of ecologically distinct faunas (abstract), Geol. Soc. Am. Abstracts Programs, 12, 144, 1980.

Olmsted, F. H., Pre-Cenozoic geology of the south half of the Auburn 15-minute quadrangle, California, U.S. Geol. Surv. Bull., 1341,30 pp., 1971.

Saleeby, J. B., Kings River ophiolite, southwest Sierra Nevada foothills, California, Geol. Soc. Am. Bull., 89, 617-636, 1978.

Saleeby, J. B., Kaweah serpentinite melange, Southwest Sierra Nevada foothills, California, Geol. Soc. Am. Bull., 90, 29-46, 1979.

Saleeby, J. B., Ocean floor accretion and volcano-plutonic arc evolution of the Mesozoic Sierra Nevada, California, in The Geotectonic Development of California, Rubey Volume 1, edited by W. E. Ernst, pp. 132-181, Prentice-Hall, Englewood Cliffs, N. J., 1980.

Saleeby, J. B., and W. D. Sharp, Chronology of the structural and petrologic development of the southwest Sierra Nevada foothills California, 2, Geol. Soc. Am. Bull., 1416-1535, 1980.

Saleeby, J. B., S. E. Goodwin, W. D. Sharp, and C. J. Busby, Early Mesozoic paleotectonic-paleogeographic reconstruction of the southern Sierra Nevada region, in Mesozoic Paleogeography of the Western United States, Paleogeogr. Symp. 2, edited by D. E. Howell and K. A. McDougall, pp. 311-336, Society of Economic Paleontogolists and Mineralogists, Pacific Section, Los Angeles, Calif., 1978.

Saleeby, J. B., J. M. Mattinson, and J. E. Wright, Regional ophiolite terranes of California-Vestiges of two complex ocean floor assemblages (abstract), Geol. Soc. Am. Abstracts Programs, 11, 509, 1979.

Schweickert, R. A., Major pre-Jurassic thrust fault between the Shoo Fly and Calaveras complexes, Sierra Nevada, California (abstract), Geol. Soc. Am. Abstracts Programs, 9, 497, 1977.

Schweickert, R. A., J. B. Saleeby, O. T. Tobisch, and W. H. Wright III, Paleotectonic and paleogeographic significance of the Calaveras Complex, western Sierra Nevada, California, in Paleozoic Paleogeography of the Western United States, Paleogeogr. Symp. I, edited by J. H. Stewart, C. H. Stevens, and A. E. Fritsche, pp. 381-394, Society of Economic Paleontologists and Mineralogists, Pacific Section, Los Angeles, Calif., 1977.

Schweickert, R. A., M. L. Bogen, G. H. Girty, R. E. Hanson, and E. Merguierian, Contrasting styles of deformation during the Nevadan orogeny, Sierra Nevada, California, Geol. Soc. Am. Bull., in press, 1982.

Sharp, W. D., Ophiolite accretion in the northern Sierra (abstract) Eos Trans. AGU, 61, 1122, 1980.

Sharp, W. D., and J. B. Saleeby, The Calaveras Formation and syntectonic mid-Jurassic plutons between the Stanislaus and Tuolumne rivers, California (abstract), Geol. Soc. Am. Abstracts Programs, 11, 127, 1979.

Sharp, W. D., and J. E. Wright, Jurassic metavolcanic sequences in the western Sierra-Klamath provinces: Character and tectonic significance, Geol. Soc. Am. Abstracts Programs, 13, 105, 1981.

Sharp, W. D., J. B. Saleeby, R. A. Schweickert, C. Merguerian, O. T. Tobisch, and W. H. Wright III, Age, petrology and tectonic significance of Paleozoic orthogneisses of the central Sierra Nevada, California, Geol. Soc. Am. Bull., in press, 1982.

Silver, L. T., The use of cogenetic uranium-lead isotope systems in zircons in geochronology, in Radioactive Dating, pp. 279-285, International Atomic Energy Agency, in cooperation with the Joint Committee on Applied Radioactivity, Athens, Nov. 1962.

Silver, L. T., The relationship between radioactivity and discordance in zircons, in Nuclear Geophysics, Publ. 1075, Nucl. Sci. Ser. Rep. 38, pp. 34-39, National Academy of Sciences-National Research Council, Washington, D.C., 1964.

Silver, L. T., A geochronologic investigation of the anorthosite complex, Adirondack Mountains, New York, in Origin of Anorthosite and Related Rocks, Mem. 18, edited by Y. W. Isachen, pp. 233-251, New York State Museum and Science Service, New York, 1969.

Silver, L. T., and S. Deutsch, Uranium-lead isotopic variations in zircons: A case study, J. Geol., 71, 721-758, 1963.

Snoke, A. W., W. D. Sharp, J. E. Wright, and J. B. Saleeby, Significance of mid-Mesozoic peridotitic to dioritic intrusive complexes, Klamath Mountains-Western Sierra Nevada, California, Geology, in press, 1982.

Springer, R. K., Contact metamorphosed ultramafic rocks in the western Sierra Nevada foothills, California, J. Pet., 15, 160-195, 1974.

Springer, R. K., Geology of the Pine Hill intrusive complex, a layered gabbroic body in the western Sierra Nevada foothills, California, Summary, 1, Geol. Soc. Am. Bull., 91, 381-385, 1980 a.

Springer, R. K., Geology of the Pine Hill intrusive Complex, a layered gabbroic body in the western Sierra Nevada foothills, California, 2, Geol. Soc. Am. Bull., 91, 1536-1626, 1980 b.

Stanton, R. L., and J. D. Bell, Volcanic and associated rocks of the New Georgia Group, British Solomon Islands Protectorate, Overseas Geol. Miner. Resour., 10, 113-145, 1969.

Tilton, G. R., C. A. Hopson, and J. E. Wright Uranium-lead 
isotopic ages of the Semail ophiolite, Oman, with application to Tethyan ocean ridge tectonics, J. Geophys. Res., 86, 2763-2775, 1981.

Wetherill, G. W., Discordant uranium-lead ages, 1, Eos Trans. $A G U, 37,320-326,1956$

Xenophontos, C., and G. C. Bond, Petrology, sedimentation, and paleogeography of the Smartville terrane (Jurassic)-Bearing on the genesis of the Smartville ophiolite, in Mesozoic Paleogeogra- phy of the Western United States, Paleogeogr. Symp. 2, edited by D. E. Howell and K. A. McDougall, pp. 291-302, Society of Economic Paleontologists and Mineralogists, Pacific Section, Los Angeles, Calif., 1978.

(Received March 5, 1981;

revised October 22, 1981; accepted November 13, 1981.) 